Portland State University

PDXScholar

$1-25-1972$

\title{
Catechol Effected Dissolution of Silicate Minerals
}

James Maurice Kelley

Portland State University

Follow this and additional works at: https://pdxscholar.library.pdx.edu/open_access_etds

Part of the Geochemistry Commons, and the Organic Chemistry Commons Let us know how access to this document benefits you.

\section{Recommended Citation}

Kelley, James Maurice, "Catechol Effected Dissolution of Silicate Minerals" (1972). Dissertations and Theses. Paper 970.

https://doi.org/10.15760/etd. 970

This Thesis is brought to you for free and open access. It has been accepted for inclusion in Dissertations and Theses by an authorized administrator of PDXScholar. Please contact us if we can make this document more accessible: pdxscholar@pdx.edu. 
AN ABSTRACT OF THE THESIS OF James ifaurice Kelley for the Master of Arts in Chemistry presented January 25, 1972.

T1tle: Catechol Effected D1ssolution of Silicate Hinerals. APPROVED BY MEMBERS OF THE THESIS COMMITTEE:

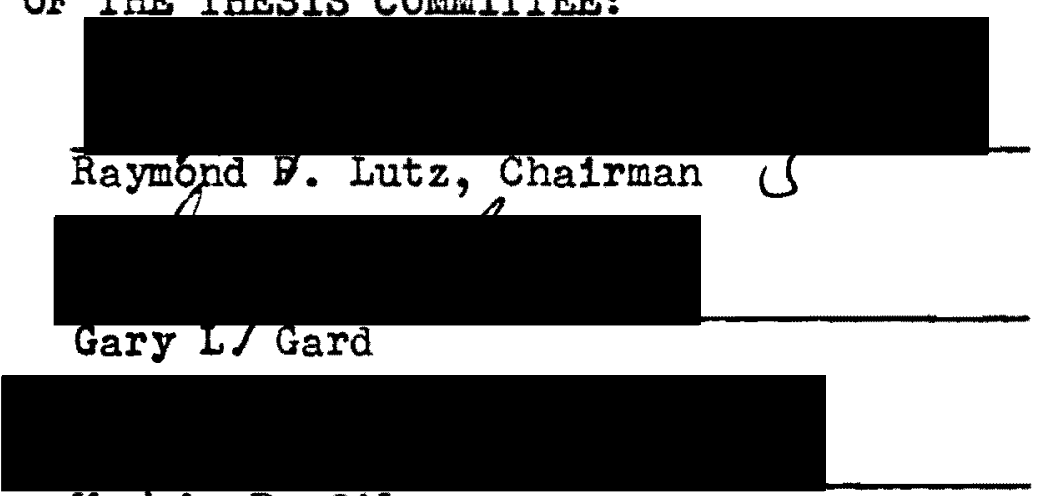

Horris B. Silverman

The chemical properties of guanidinium tris(catecholato) siliconate, $\left[\left(\mathrm{H}_{2} \mathrm{~N}\right)_{2} \mathrm{C}=\mathrm{NH}_{2}\right]_{2}\left[\mathrm{~S}_{1}\left(\mathrm{C}_{6} \mathrm{H}_{4} \mathrm{O}_{2}\right) 3\right]-\mathrm{XH}_{2} \mathrm{O}(\mathrm{O}<\mathrm{X} \leq 1)$, precipitated from an ammoniacal solution of silica and catechol by adding guanidintum hydrochloride, $\left(\mathrm{H}_{2} \mathrm{~N}\right)_{2} \mathrm{C}=\mathrm{HH} \cdot \mathrm{HCl}$, mere studied, and infrared, nmr, x-ray powder diffraction, and analytical data were gathered.

This same compound was, upon addition of $\left(\mathrm{H}_{2} \mathrm{~N}\right)_{2} \mathrm{C}=\mathrm{NH} \cdot \mathrm{HCl}$, 1solated from $0.25 \mathrm{~W}$ aqueous catechol solutions buffered at pH 10 and containing the silicate minerals albite, andradite, muscovite, pyrophyllite, talc, and wollastonite, and also from unbuffered catechol solutions containing wollastonite. and andradite. 
It is concluded from this work that the formation of

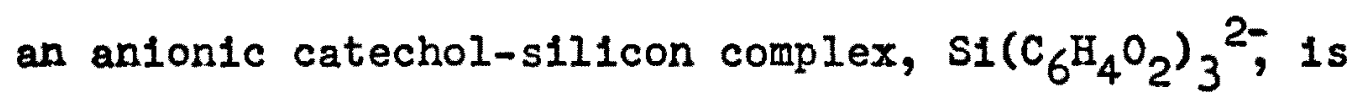
largely responsible for the dissolution of the minerals mentioned above. From this conclusion, it is proposed that naturally occurring members of the class of organic compounds to which catechol belongs, the aromatic vic-diols, may play a role in chemical weathering, in the development of certain soil profiles, and in the entry and accumulation of silica in plants. 
CATECHOL EFFECTED DISSOLUTION OF SILICATE NINERALS

\author{
by \\ JAMES MAURICE RELLEY
}

A thesis submitted in partial fulfillment of the requirements for the degree of

\title{
MASTER OF ARTS \\ in \\ CHEMISTRY
}

Portland State University

1972 
TO THE OFFICE OF GRADUATE STUDIES:

The nembers of the Committee approve the thesis of James Maurice Kelley presented January 25, 1972.

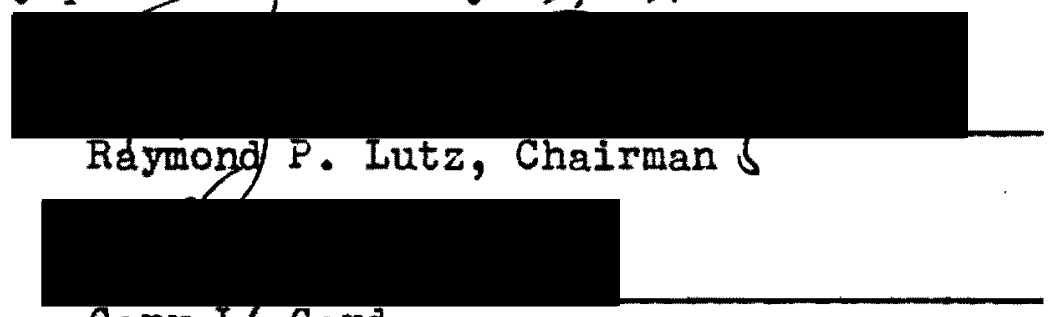

Gary Ll Gard

Worris B. Silverman

APPROVED:

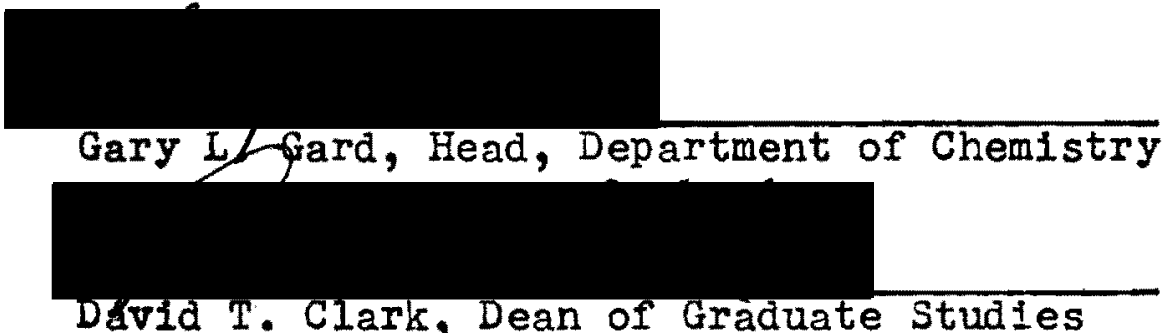

Apr11 7, 1972 


\section{ACKNOWLEDGEMENTS}

I wish to thank Dr. Dennis W. Barnum, who suggested and directed this research, for his assistance in providing equipment and materials, for his suggestions, and for his help in preparing this manuscript. I also wish to extend my gratitude to Dr. Raymond P. Lutz for his help in the interpretation of nmr spectra. To my good friend Boonthong Poocharoen, who has worked with me these many months, I wish to express special appreciation for his generosity in sharing his equipment, materials, and his knowledge. 
TABLE OF CONTENTS

PAGE

ACRNOWLEDGEMENTS

LIST OF TABLES

$\mathbf{v 1}$

CHAPTER

I INTRODUCTION . . . . . . . . . . . 1

II PREPARATION, PROPERTIES, AND STRUCTURE OF

GUANID IN IUN TRIS (CATECHOLATO) SILICONATE . 8

Introduction . . . . . . . 8

Experimental . . . . . . . 9

Preparation

Properties

structure . . . . . . . . .

III REACTIONS BETWEEN SILICATE MINERALS AND CAT-

ECHOL IN BUFFERED AQUEOUS MEDIA . . . . 22

Introduction ......... 22

Experimental ........... 22

Description of Uinerals

Initiation of Reactions

Treatment of Reaction Mixtures

Results . . . . . . . 28

Discussion ........ 30

IV REACTIONS BETWEEN SILICATE MINERALS AND CAT-

ECHOL IN UNBUFFERED AQUEOUS LEDIA . • . 36

Introduction . . . . . . . 36

Experimental ......... 36

Description of Minerals 
Preparation of Guanidinium Tris(catecholato) siliconate from Wollastonite

Preparation of Guanidinium Tris(catecholato) siliconate from Andradite

Reactions of Diopside, Talc, and White Beryl with Catechol

Preparation of an Unidentifled Calclum Salt, Compound $A$, from Wollastonite

Discussion of Results . . . . . . .

The Dissolution of Silicate Uinerals Description of Compound $A$

REFERENCES . .

APPENDIX

A X-RAY POWDER DIFFRACTION PATTERN, INFRARED AND NHR SPECTRA, AND EQUTVALENT CONDUCTANCE OF GUANIDIN IUM TRIS(CATECHOLATO) SILICONATE . . 48

B X-RAY POWDER DIFFRACTION PATTERNS OF SILICATE MINERALS AND SIIICATE MINERAL REACTION RESIDUES

C X-RAY POWDER DIFFRACTION PATTERN AND INFRARED AND NUR SPECTRA OF AN UNIDENTIFIED CALCIUM SALT, COLPOUND A 


\section{LIST OF TABLES}

TABLE

PAGE

I Analytical Data for $\left[\left(\mathrm{H}_{2} \mathrm{~N}\right)_{2} \mathrm{C}=\mathrm{NH}_{2}\right]_{2}\left[\mathrm{SI}(\mathrm{Cat})_{3}\right] \mathrm{XH}_{2} \mathrm{O}$. 12

II Description of ifinerals . . . . . . . . 22

III Summary of the Results Following Reactions of

Silicate Minerals with Catechol in Buffered

Aqueous Media............. 29 


\section{INTRODJCTION}

Silicate minerals comprise about $90 \%$ of the earth's crust. Although a wide variety of different silicates ex1st, they all have as their basic structural unit the silica tetrahedron in which silicon is, or is approximately, equidistant from four oxygens.

Because of the ublquity of silicon compounds in nature, studies dealing with the breakdown of silicates followed by the formation of secondary products constitutes a major area of research. For example, geochemists continually seek to explain various weathering phenomena by proposing mechanisms which generally incorporate well estabIIshed inorganic reactions. Such mechanisms must, of course, obey the laws of chemical equilibrla and also meet the criterla 1mposed by nature. These mechanisms are often quite satisfactory and can, in many cases, be tested in the laboratory.

Too often, though, classical mechanisms fall to provide the answers. Evans (1) points out that there are many examples where sediments like quartzites and limestones have consolidated rapldiy under mild environmental conditions. In such cases, mechanisms embodying pressure and long periods of time must be ruled out, and the role which organic matter might play in geochemical events deserves serious 
consideration.

Natural weathering environments usually contain organic matter originating from root secretion, decomposition of plant debris, and even the leaching of live plants. Trace amounts of organic matter are found in ancient sedimentary rocks, and Iler (2, p.3) cites an unusual example where quartz crystals have formed with inclusions of mineral oil and liquid carbon dioxide.

There is a class of organic compounds, the aromatic Vic-diols,* whose presence in natural environments has recently been suggested in connection with studies dealing with water quality (3) and soll development $(4,5)$. Compounds from this class are relatively stable against bacterial attack which increases the likelihood that they will persist in natural environments for significant periods of time. It is interesting to note, that while both of the studies clted above focused on the 1ron complexing properties of aromatic vic-diols, these diols also constitute the only class of organic compounds known to form water stable silicon complexes.

A wide variety of aromatic Vic-diol-silicon complexes have been prepared and investigated $(6,7,8,9,10)$. The aromat1c V1c-diols known to form complexes with silicon are

* A vic-diol is an organic compound with at least tro hydroxy groups attached to adjacent carbons. Ethylene glycol is the simplest vic-diol, and catechol is the simplest aromatic vic-diol. 
pyrogallol, alizarin, purpurin, gallic ac1d, quercetin, catechol, tannic acid--tannic acids are found in natural surface waters (II)--and several more. Qulte generally, the ratio of aromatic vic-diol to silicon $153: 1$. It is fairly certain that should one of these compounds fall to form a complex with silicon, it would be the exception rather than the rule.

The possible involvement of organic matter in geochem1cal processes has not been Ignored; however, thought usually centers around mineral dissolution resulting from chelation of metallic cations $(1,12, \mathrm{p} .47)$. Although mechanisms involving chelation of cations show promise in resolving many chemical weathering anomalies, and help to explain how certain soll profiles formed, mechanisms involving organlc-silicon complexes have been overlooked.

The theory that aromatic vic-diols are involved in the development of solls of the podsol* group has received considerable attention by soil scientists. Bloomfield (4) has

* Podsols, the most widely distributed of the humid climate soll groups, exhibit well developed $A, B$ and $C$ horlzons (layers). The A or eluvial (washed-out) horizon is usually subdivided into three parts: the Ao horizon consists of forest litter and partially decayed organic matter, the $A_{1}$ horizon consists of raw humus, and the $A_{2}$ horlzon is a siliceous grey layer from which iron and aluminum have been leached. The $B$ or 1lluvial (washed-in) horizon is subdivided into two parts: the $B_{1}$ horizon consists of precipitated humus, and the $\mathrm{B}_{2}$ horizon consists of sesquioxides $\left(\mathrm{Fe}_{2} \mathrm{O}_{3}\right.$ and $\mathrm{Al}_{2} \mathrm{O}_{3}$ ) and colloidal clay. The $C$ horizon consists of weathered bedrock. Both the A and $B$ horizons are strongly acldic. 
shown that polyphenolic extracts of forest leaves and litter effectively complexes and dissolves iron and aluminum oxides. Percolation of rain water through forest litter is belleved to result in the leaching of 1 ron and aluminum from the $\mathrm{A}_{2}$ horizon. The complexed iron and aluminum then move down the soll profile until immobilized and redeposited in the B horizon as sesquioxides. This theory is quite plausible, especially when compared with alternatives, and is gaining acceptance. It would be even more plausible if it were shown that dissolution of the parent mineral from which sesquioxides are leached is effected not only by chelation of iron and aluminum, but also by formation of polyphenol-silicon (1.e., aromatic vic-diol-silicon) complexes.

It has already been established that basic solutions containing aromatic vic-diols are effective in dissolving silica, whether it be in the form of an amorphous gel or crystalline quartz $(6,7)$. Also Hess, Bach and Deuel (13) reported that an ammoniacal solution containing catechol was effective in dissolving permutite, a synthetic amorphous aluminum silicate, and somewhat less effective in dissolving perlite, a naturally occurring amorphous aluminum silicate. They also mentioned that under the same conditions an insoluble brown coating formed on the potash feldspar, orthoclase. They did not attempt to isolate or identify the reaction products.

Kononova et al (14) treated sone silicates (1.e., lep- 
1domelane, kaolinite, nepheline and plagloclose) with certain organic and Inorganic substances fourid in soll matter. They reported that tartaric acid, catechol ard humlc acids mere effective in dissolving these minerals. Fhey noted that mineral dissolution was accompanied by rise in $\mathrm{pH}$. Solutions were electrophoretically fractionatad and cations vere detectected as organometallic compouncs. There was no Indication that the possible formation of sicon complexes was considered.

Silica itself is found in many forms jant life and In some animals. Blogenically precepitated .ilca is almost always an amorphous variety, ranging from 0 . ine forms secreted by radiolaria, diatoms and sponges, the gelatinous "tablsher" found in the hollow stems of bas:. There are reports (1), though, where crystalline sil: in the form of quartz aggregates, was found in kidney $s:$ is of human belngs who were treated for peptic ulcers $\because d:$ a synthetic silicate of zeolitic structure. Such occur: ces are also reported as being common with sheep that fes: on certain types of hay having a high silica content.

The manner in which silica enters and cumulates in plants is not completely understood. Sieven nd Scott (15) mention that although it is reasonable to ${ }^{2}$ ibute the accumulation of silica in most plants to the poration of sllica rich fluids, another mechanism must c rate for diatoms since they secrete silica under water. It would seem 
that such a mechanism requires the involvement of a transient organic-silicon complex.

Iler (2, p.290) recounts an investigation of the mechanism by which silica is brought into solution by the roots of rye and sunflower. Silica accumulates in the shoots and leaves of these plants indicating that soluble silica moves along the transpiration stream--it does this with most plents which accumulate silica. When the rye and sunflower were grown in clay, the roots secreted a substance which brought silica into solution. It was speculated that soluble silicic acid was then absorbed by the plants. Since the root secretion apparently dissolved the clay silicate, it likely did so by chelation of metallic constituents. It can be speculated, however, that silicon itself also could have been complexed and perhaps absorbed by the plant as a complex rather than as silicic acid. Iler aptly points out that this study furnishes an excellent example of the role of plants in weathering of rocks and formation of solls. In this case it is a dual role involving mechanical breakdown of rocks as plants grow and roots spread, and chemlcal breakdown as root secretions dissolve minerals allowing the removal of soluble silica.

This work is a continuation of the attempt to demonstrate the effectiveness of organic matter in dissolving silicate minerals. However, emphasis is placed upon the 1mportance of the formation of silicon complexes. Since, as 
was mentioned, aromatic ric-diols are the only organic compounds known to form water soluble complexes with silicon, the simplest one, catechol, was chosen for these studies. The guanidinium salt of the catechol-silicon complex was characterized since it was chosen to be 1solated in subsequent reactions of catechol with silicate minerals. following inftial studies of the solubilization of silicate minerals by catechol in buffered aqueous media, reactions with the minerals wollastonite and andradite were investigated in more detail. 
II. PREPARATION, PROPERTIES, AND STRUCTURE OF GUANIDINIUN TRIS (CATECHOLATO) SILICONATE,

$\left[\left(\mathrm{H}_{2} \mathrm{~N}\right)_{2} \mathrm{C}=\mathrm{NH}_{2}\right]_{2}\left[\mathrm{SI}(\mathrm{Cat})_{3}\right] \cdot \mathrm{XH}_{2} \mathrm{O*}$

\section{INTRODUCTION}

The guanidinium salt of the catechol-silicon complex was first prepared by Rosenheim et al (6). A solution containing an excess of freshly precipitated silica, $\mathrm{S1O}_{2}$, was treated with catechol and sodium hydroxide, the unreacted silica was filtered off, and guanidinlum hydrochloride, $\left(\mathrm{H}_{2} \mathrm{~N}\right)_{2} \mathrm{C}=\mathrm{NH} \cdot \mathrm{HCl}$, was added to the filtrate. A guanidinium salt, which was reported to be a seven-hydrate, precipitated.

We1ss et al (7) reported the preparation of a dimeric tetrahydrated guanidinium salt, $\left[\left(\mathrm{H}_{2} \mathrm{~N}_{2} \mathrm{C} \mathrm{C}=\mathrm{NH}_{2}\right]_{4}\left[\mathrm{SI}_{2}(\mathrm{Cat})_{6}\right] \cdot 4 \mathrm{H}_{2} \mathrm{O}\right.$, from an analogous ammonium salt, $\left[\mathrm{NH}_{4}\right]_{4}\left[\mathrm{SI}_{2}(\mathrm{Cat})_{6}\right] \cdot 9 \mathrm{H}_{2} \mathrm{O}$. The guanidinium salt was precipitated from an aqueous solution of the ammonium salt at a pH between 6.0 and 6.5 by adding aqueous guanidinium carbonate, $\left(\mathrm{H}_{2} \mathrm{~N}\right)_{2} \mathrm{C}=\mathrm{NH} \cdot \mathrm{H}_{2} \mathrm{CO}_{3}$. The recovered product was washed with ether.

The degree of hydration of the guanidinfum salt prepared in the present work is uncertain; it does not, however,

* The following abbreviations will be used to represent catechol and its ions in this paper:

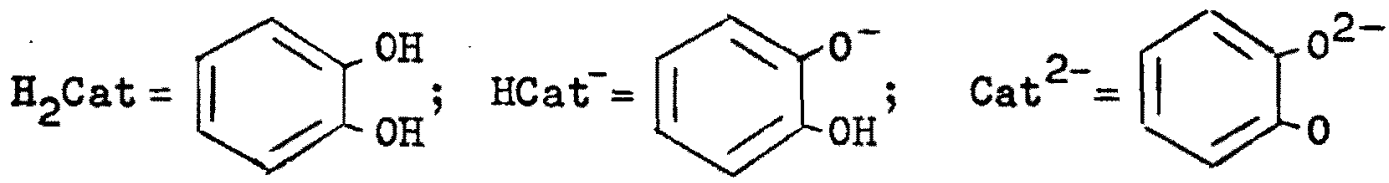


contain more than one mole of water. X-ray, infrared, and nmr studies of this salt are included in this paper.

\section{EXPERIMENTAL}

Preparation of $\left[\left(\mathrm{H}_{2} \mathrm{~N}\right)_{2} \mathrm{C}=\mathrm{NH}_{2}\right]{ }_{2}\left[\mathrm{SI}(\mathrm{Cat})_{3}\right] \cdot \mathrm{XH}_{2} \mathrm{O}$ From Sillcle Acld

Since catechol is easily oxidized, especially in basic media, it is necessary to carry out this preparation in a nitrogen atmosphere. Introduce $15 \mathrm{~g}$ of catechol into a 250ml round bottom flask to wh1ch a side arm with a straight bore stopcock is attached. Insert a ground glass stopper into the neck of the flask, evacuate the flask through the slde arm and then bleed in nitrogen. Prepare an ammonlacal solution of silica by adding $2-3 \mathrm{~g}$ of silicic acld to about $200 \mathrm{ml}$ of concentrated (15 M) ammonium hydroxide. Stir for about one hour and then filter of the undissolved silica. Fit a rubber serum cap to the side arm of the round bottom flask and, using a hypodermic syringe, introduce $175 \mathrm{ml}$ of the filtered ammoniacal silica solution through the serum cap and open bore of the stopcock. St1r thoroughly unt1l all of the catechol dissolves. Then, in the same manner, introduce $35 \mathrm{ml}$ of 4 in guanidinfum hydrochloride solution. A precipitate begins to form within a few minutes. After one hour, precipitation appears to be complete. Filter the preclpitate under nitrogen, wash with small portions of cold $I U$ ammonium hydroxide, and dry to constant weight in a vacu- 
um at room temperature. The yleld is about $1 \frac{1}{2}$ g.*

Properties of $\left[\left(\mathrm{H}_{2} \mathrm{~N}\right)_{2} \mathrm{C}=\mathrm{NH}_{2}\right] 2[\mathrm{SI}(\mathrm{Cat}) 3] \cdot \mathrm{XH}_{2} \mathrm{O}$

The dry guanidinium salt is a white powder which is somewhat hygroscopic. It begins to discolor in air after about one month. Thus, it can be handled in air but should be stored under nitrogen. The guanidinium salt is only slightly soluble in water; the solubility was found to be $0.50 \mathrm{~g} / 100 \mathrm{cc.**}$ It is soluble in DHso to the extent of at least $12 \mathrm{~g} / 100 \mathrm{cc}$. It $1 \mathrm{~s}$ considerably less soluble in ethanol than in water and is insoluble in diethyl ether and acetone. In dilute aqueous acid solutions, the guanidinium salt decomposes to regenerate catechol and silica; the catechol goes into solution and the silica precipitates.

Analytical data obtained for $\left[\left(\mathrm{H}_{2} \mathrm{~N}\right)_{2} \mathrm{C}=\mathrm{NH}_{2}\right] 2\left[\mathrm{Si}(\mathrm{Cat})_{3}\right] \cdot \mathrm{XH}_{2} \mathrm{O}$ prepared from silicic acid and also from the sillcate mineral wollastonite (the preparation of the guanidinium salt

* Equilibrium studies by Baumann (10) show that under the basic conditions of this reaction, dissolved silica is quantitatively converted to the anionic catechol-silicon complex. Therefore, since a large excess of guanidinium Ions were present, and the guanidinium salt of the catecholsilicon complex is cnly very slightly soluble, it is likely that if the yield is not quartitative with respect to the amount of silica present, it is very high. However, the amount of silica present in the concentrated ammonia solution depends upon the rate of dissolution, and thus varies with the amount of silica added, its specilic surface area, and the time and temperature of stirring.

** Heasured in a $\mathrm{pH} 7.5 \mathrm{H}_{2} \mathrm{CO}_{3} / \mathrm{HCO}_{3}$ - buffer solution; 1onic strength $=0.05$. 
from wollastonite is described in Part IV) are presented in Table I. The high molecular weight of the catechol-silicon complex makes any decision regarding the degree of hydration somewhat uncertain. Nevertheless, the data agree best vith a salt containing one half mole of water. A salt containing more than one mole of water can almost be ruled out. The disagreement between the degree of hydration of the salt prepared in this work with that of salts prepared by Rosenheim and Weiss arises because neither Rosenheim nor Weiss dried their products to constant weight under vacuum. $X$-ray powder diffraction data are presented in Table A-1, Appendix A. There is no detectable difference between the powder patterns of the salt prepared from silicic acid and the salt prepared from wollastonite.

The infrared spectrum of $\left[\left(\mathrm{H}_{2} \mathrm{~N}\right)_{2} \mathrm{C}=\mathrm{NH}_{2}\right]_{2}\left(\mathrm{Si}(\mathrm{Cat})_{3}\right) \cdot \mathrm{XH}_{2} \mathrm{O}$ is shown in Figure A-1, Append1x A. The bands at $2.95 \mu$ and $3.18 \mu$ are believed to be due to symmetric and asymmetric $\mathrm{N}-\mathrm{H}$ stretching modes and are well resolved compared to the corresponding bands for most guanidinium salts (e.g., guanidintum hydrochloride, $\left(\mathrm{H}_{2} \mathrm{~N}\right)_{2} \mathrm{C}=\mathrm{NH} \cdot \mathrm{HCl}$, exhibits a relatively broad band centered at about $3.0 \mu$ with a barely visible shoulder at $3.18 \mu$ ). Upon close examination of the $N-H$ stretching bands, two shoulders are seen--one at about $2.8 \mu$ and the other at about $3.1 \mu$. A high resolution spectrum (not shown) reveals distinct absorption bands where the 
TABLE I

ANALYTICAL DATA FOR $\left[\left(\mathrm{H}_{2} \mathrm{~N}\right)_{2} \mathrm{C}=\mathrm{NH}_{2}\right]_{2}\left[\mathrm{SI}(\mathrm{Cat})_{3}\right] \cdot \mathrm{XH}_{2} \mathrm{O}$

\begin{tabular}{|c|c|c|c|c|c|c|c|}
\hline & \multicolumn{4}{|c|}{ Theory } & \multirow{2}{*}{$\begin{array}{c}\text { Prep from } \\
\text { Silicic } \\
\text { Acld }\end{array}$} & \multirow{2}{*}{\multicolumn{2}{|c|}{$\begin{array}{l}\text { Prep. from } \\
\text { Wollastonite }\end{array}$}} \\
\hline & $x=0$ & $x=1 / 2$ & $x=1$ & $x=3 / 2$ & & & \\
\hline$c$ & 50.84 & 49.86 & 48.97 & 48.09 & 50.39 & 48.53 & 49.69 \\
\hline $\mathrm{H}$ & 5.12 & 5.23 & 5.34 & 5.45 & 5.24 & 5.01 & 5.27 \\
\hline$N$ & 17.78 & 17.45 & 17.13 & 16.82 & 17.18 & 16.71 & 16.56 \\
\hline S1 & 5.94 & 5.83 & 5.73 & 5.62 & 5.81 & 5.96 & 6.25 \\
\hline $0^{2}$ & 20.32 & 21.60 & 22.83 & 24.02 & $(21.38)$ & $(23.79)$ & $(22.23)$ \\
\hline
\end{tabular}

1 The samples prepared from wollastonite contalned traces of Iron complexed with catechol which might influence the analytical data slightly; the data obtained for the pure guanidinium salt prepared from silicic acid should be quite reliable.

2 Values for oxygen in parentheses are calculated by difference from 100\%. 
shoulders appear in the lower resolution, spectrum.* These bands very possibly arise from intra- and intermolecular hydrogen bonding $0-\mathrm{H}$ groups which exhibit stretching bands at $2.78-2.86 \mu$ and $2.94-3.13 \mu$ respectively; the aromat1c C-H stretching band should appear at a higher wavelength $(\sim 3.3 \mu$ ) and would not necessarily be seen (i.e., the C-H stretching band is likely hidden in the $\mathrm{N}-\mathrm{H}$ stretching band at $3.18 \mu$ ).

Two absorption bands are seen in the $\mathrm{C}-\mathrm{H}$ in-plane bending region--one at $9.14 \mu$ and the other at $9.82 \mu$. The location of these bands is an important feature of the infrared spectrum of the catechol-silicon complex since the shifts from positions at 9.10 and $9.59 \mu$ found for catechol Itself provide evidence that a chelate is formed; similar shifts have been observed for three other salts of the $3: 1$ catechol-silicon ester.** A spectrum run from a nujol mull preparation reveals that the band at $9.14 \mu \mathrm{is,}$, for the guanidinium salt of the complex, actually a closely spaced doublet (see Figure A-2, Appendix A).

The nmr spectrum of $\left[\left(\mathrm{H}_{2} \mathrm{~N}\right)_{2} \mathrm{C}=\mathrm{NH}_{2}\right]_{2}\left[\mathrm{SI}(\mathrm{Cat})_{3}\right] \cdot \mathrm{XH}_{2} \mathrm{O}$ in

* The author wishes to thank $\mathrm{Hr}$. Boonthong Poocharoen for providing a high resolution infrared spectrum of $\left[\left(\mathrm{H}_{2} \mathrm{~N}\right)_{2} \mathrm{C}=\mathrm{NH}_{2}\right]_{2}\left[\mathrm{SI}(\mathrm{Cat})_{3}\right] \cdot \mathrm{XH}_{2} \mathrm{O}$.

** Infrared spectra of salts of the catechol-silicon complex have not been published. However, shifts of infrared bands located between 9 and $10 \mu$ (believed to be associated with aromatic $\mathrm{C}-\mathrm{H}$ in-plane bending) have been observed upon formation of pyridinium, ammonium and magnesium salts prepared in this laboratory by the author and coworkers. 
deuterated DMSO is shown in Figure A-3, Appendix A. Two peaks are observed--one at $13.72 \mathrm{ppm}$ and the other at $\uparrow 3.45 \mathrm{ppm}$.

If small quantities of guanidinium hydrochloride are added to the sample, the peak at $\uparrow 3.45 \mathrm{ppm}$ w1l shift downfleld and approach $12.75 \mathrm{ppm}$--the location of the proton peak for guanidinium hydrochloride 1tself. If, however, microliter amounts of water are successively introduced, the peak at $T 3.45 \mathrm{ppm}$ will move upfield towards the residual DusO proton peak. As the water concentration increases, hydrogen bonding becomes 1mportant and the peak begins to move back downfleld approaching $T 5.25 \mathrm{ppm}$. Clearly, the peak at $\uparrow 3.45 \mathrm{ppm}$ is due to guanidinium protons which are quite capable of undergoing rapid exchange with hydroxylic protons. Hence, even if the complex should be a hydrate, the hydroxylic protons would be averaged with the guanidinium protons. The resultant peak would appear at a concentration-dependent, intermediate position. The fact that the peak at $T 3.45 \mathrm{ppm}$ is upfield from $T 2.75 \mathrm{ppm}$ suggests that guanidinfum protons could be exchanging either with free water protons or $\mathrm{Si}-\mathrm{OH}$ protons.

There is, however, another explanation for the upfield location of the guanidinium proton jeak. Conductivity studies clearly reveal 1on-pair formation in DuSO at concentrations as low as $10^{-4} \mathcal{\Psi}$ (see Figure A-4, Appendix A). Bence, the possibility of ring current shielding of the 
guanidinium protons is not unlikely. In fact, the fleld generated by the very moblle $\pi$ electrons of the guanidinium Ion might in turn be shielding phenyl protons. The phenyl proton peak at $13.72 \mathrm{ppm}$ is upfield from $\uparrow 3.29 \mathrm{ppm}$ where the peak is found for catechol. Also, while catechol exhibIts a symmetrical $\mathrm{A}_{2} \mathrm{~B}_{2}$ splitting pattern, the complexed catechol shows just a single peak.

Even without Ion-pair formation, though, the chemical shift of the phenyl protons of the complex would be expected to differ from that of the free catechol protons. Assuming that the complex is hydrated, all factors just discussed are 1ikely operating to establish the shift positions observed for this spectrum.

The nmr spectrum of $\left[\left(\mathrm{H}_{2} \mathrm{~N}\right)_{2} \mathrm{C}=\mathrm{NH}_{2}\right]_{2}\left[\mathrm{Si}(\mathrm{Cat})_{3}\right] \cdot \mathrm{XH}_{2} \mathrm{O}$ prepared from wollastonite exhiblts only a single peak at $13.72 \mathrm{ppm}$. The absence of the guanidinium proton peak was shown to be due to a spin-lattice relaxation effect resultIng from a trace amount of paramagnetic iron. When $1.0 \mathrm{ml}$ of a DWSO solution contalining $2.3 \%$ of iron(III) was introduced into an nmr tube containing an $8.4 \%$ Duso solution of the complex prepared from sillcic acid, the guanidinium proton peak disappeared completely. The electron magnetic moment is more than one thousand times greater than nuclear magnetic moments, and so it is not surprising that such a drastic reduction of the spin-lattice relaration time for the exchanging guanldinium protons is observed. As substan- 
tially larger quantities of iron(III) are introduced, the phenyl proton peak begins to broaden.

In some preparations from wollastonite, the guanidinium proton peak was actually detected; however, it was very broad. Th1s shows that 1ron was present only in trace quantities. If not observed, the guanidinium proton peak will emerge if a few microliters of water are added. The resultant peak will, of course, be broad and shifted slightly upfield.

An anhydrous guanidinium salt of the catechol-silicon complex would exhibit a phenyl to guanidinium proton ratio of 12:12, while a monohydrate would show peaks which should integrate 12:14. Two spectra run in freshly distilled Diso Integrated 12:14.03 and 12:14.38. A th1rd spectrum which was run in deuterated DwSO integrated 12:14.27. However, a spectrum of the deuterated solvent 1tself revealed that water was present. The integral of the water proton peak was compared to that of the residual Dwso proton peak. From this relationship, it was possible to subtract the contribution of water originally present in the solvent from the integral of the guanidinium-water proton peak. The result was a ratio of 12:11.97. These conflicting results, coupled with the dublous rellability of integrals taken on closely spaced peaks, makes it necessary to admit that the integral data are inconclusive and do not reveal the degree of hydration of the salt prepared in this work. 
STRUCTURE OF $\left.\left[\left(\mathrm{H}_{2} \mathrm{~N}\right)_{2} \mathrm{C}=\mathrm{NH}_{2}\right]\right]_{2}\left[\mathrm{Si}(\mathrm{Cat})_{3}\right] \cdot \mathrm{XH}_{2} \mathrm{O}$

Silicon is normally thought of as having a coordination number of four. A familiar exception is the hexacoordinated fluorosilicate ion, $\operatorname{SiF}_{6}{ }^{2-}$. Iler (2, p.18) prefers to think of the silicon atom as having a coordination number of six in basic solutions. He states that in this ray it is easier to visualize the probable mechanism by which polymerization of silica occurs. He further points out that while silica and silicates contain tetracoordinated silicon, the picture changes when the coordinating oxygens are present as hydroxyl groups. The reason given is that the $\mathrm{OH}^{-}$ion resembles the $\mathrm{F}^{-}$ion because of penetration of the $\mathrm{O}^{2-}$ electron cloud by the $\mathrm{H}^{+}$ion. In this way, the diameter of the $\mathrm{OH}^{-}$ion is reduced by polarization. It is true that $\mathrm{F}^{-}$ions of ten replace $\mathrm{OH}^{-}$ions in many silicate minerals. Iler reasons that since the fon $\mathrm{SiF}_{6}{ }^{2-}$ exists, $\mathrm{Si}(\mathrm{OH})_{6}{ }^{2-}$ should also exist.

Flynn and Boer (16) furnish examples of some less common compounds in which sillicon is belleved to have a coordination number of six. Among these are silicon acetylacetonates, silicon imidodiphosphinates and fluorosilicate-like compounds, $\mathrm{SiF}_{5} \mathrm{R}^{2-}$. They also furnish references to $\mathrm{x}$-ray studies on a number of pentacoordinated silicon compounds of which I is an example. 


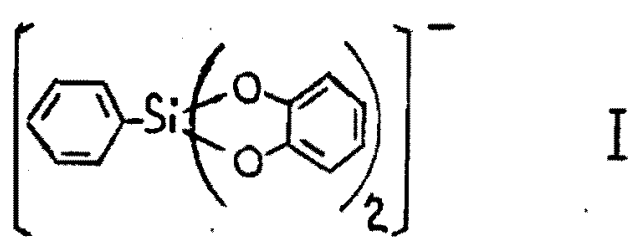

Rosenhe1m (6), who first prepared the guanidinium salt of the catechol-silicon complex (as well as other salts), concluded that silicon was hexacoordinated by three catechol groups to form a monomeric anion as depicted by II.

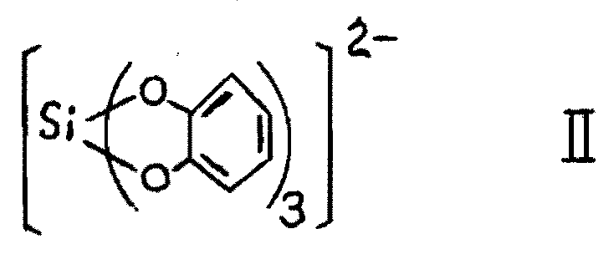

Heiss (7) proposed some more complicated dimeric structures; however, his arguments have been challenged by Barnum (17), Frye (18) and Flynn (16). As a matter of fact, Flynn's single crystal $x$-ray study undertaken on an anhydrous pyridinium salt, $\left[\mathrm{C}_{5} \mathrm{H}_{5} \mathrm{NH}\right]_{2}$ ( $\mathrm{Si}$ (Cat) $\left.)_{3}\right]$, has quite convincingly shown that the complex is monomeric with silicon octahedrally coordinated by three catecholate groups as shown in III.

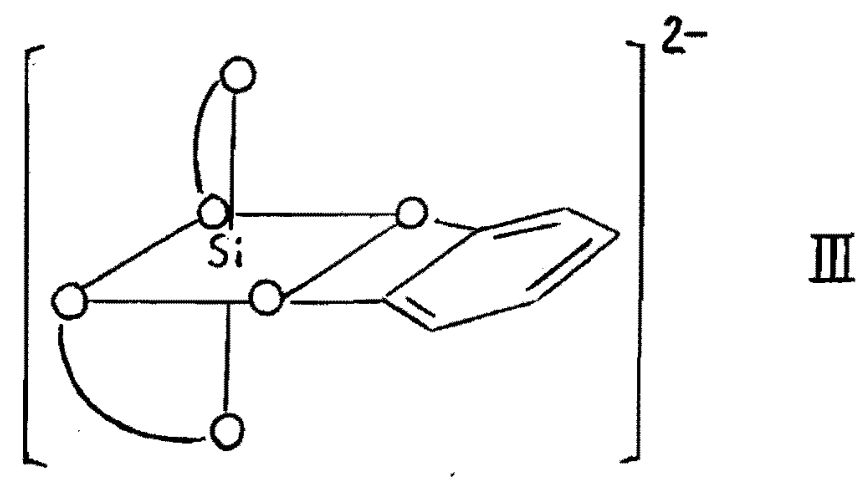


That the guanidinium salt prepared in this work is probably hydrated is, as was pointed out earlier, suggested by the analytical data, the infrared spectrum and, to a lesser extent, by the nmr spectrum. It would be tempting to say, on the basis of the analytical data, that the complex contains one half mole of water as an occlusion in the crystal latt1ce. However, Barnum (17) reported preparing an ammonium salt according to the directions given by Rosenheim and Sorge (8) in which the product vas recovered from an ethanol solution with water rigorously excluded. The purpose was to 1solate an anhydrous salt. However, the recovered salt, $\left[\mathrm{NH}_{4}\right]_{2}\left[\mathrm{~S} 1\left(\mathrm{OC}_{2} \mathrm{H}_{5}\right)(\mathrm{HCat})(\mathrm{Cat})_{2}\right]$, contained a mole of "ethanol" believed to be present as $\mathrm{Si}-\mathrm{OC}_{2} \mathrm{H}_{5}$ and H-Cat groups. Upon contact with air, the ethoxy compound is converted to a monohydrate. Furthermore, the water from $\left[\mathrm{NH}_{4}\right]_{2}\left[\mathrm{Si}(\mathrm{Cat})_{3}\right] \cdot \mathrm{H}_{2} \mathrm{O}$ cannot be removed even after heating to $60^{\circ} \mathrm{C}$ in a vacuum for two weeks. The conclusion was that a simple water of hydration was not involved, but instead the "water" was incorporated as an S1-OH group plus a phenolic hydrogen as depicted in structure IV. Barnum (19) also

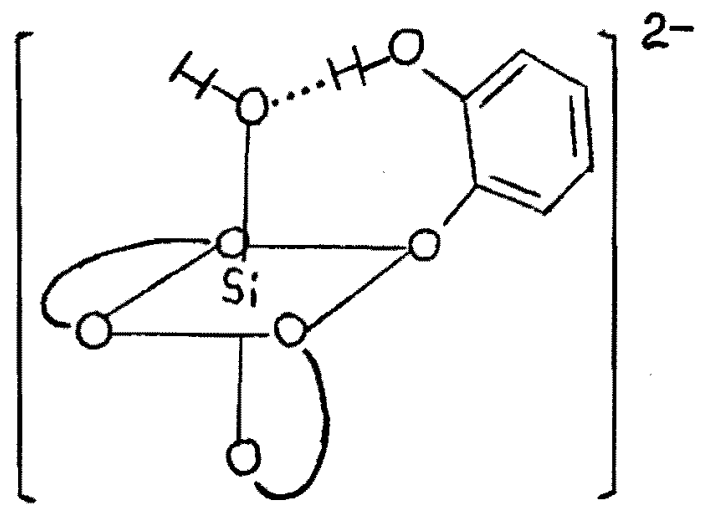


points out that the ammonium salts of analogous complexes (1.e., $\left[\mathrm{NH}_{4}\right]_{2}\left[\mathrm{~W}(\mathrm{Cat})_{3}\right] \cdot \mathrm{H}_{2} \mathrm{O}$, where $\mathrm{W}$ can be germantum, $\mathrm{tin}$ or niobium as well as silicon), and different salts of octahedrally coordinated arsenic, tin and iron complexes of catechol all contain a mole of strongly held water.

All of the samples prepared in this work were taken to constant reight in a vacuum. Some samples remained in a vacuum for as long as three days. If the guanidinium salt prepared here is hydrated, it is probably a monohydrate which would be best represented by structure IV and best formulated as $\left[\left(\mathrm{H}_{2} \mathrm{~N}\right)_{2} \mathrm{C}=\mathrm{NH}_{2}\right]_{2}\left[\mathrm{Si}(\mathrm{OH})\right.$ (HCat)(Cat) $\left.{ }_{2}\right\}$. 


\section{REACTIONS BETWEEN SILICATE MINERALS \\ AND CATECHOL IN BUFFERED \\ AQUEOUS MEDIA \\ INTRODUCTION}

The possible involvement of aromatic vic-diols in weathering and soil formation was discussed in Part $I$. The work described in this section was undertaken to determine whether aqueous solutions containing catechol will attack silicate minerals. Slbite, andradite, muscovite, pyrophyllite, talc and wollastonite were treated vith aqueous catechol solutions buffered at $\mathrm{pH} 10$; in addition, wollastonite and pyrophyllite were treated with $\mathrm{pH} 4$ catechol solutions. These minerals were chosen for this investigation because they are available in relatively pure form and represent four of the six sillcate mineral subclasses (1.e., the tekto-, neso-, phyllo-, and inosilicates).

\section{EXPERIMENTAL}

\section{Description of Minerals}

The minerals used in this work are described in Table II. They were crushed in a percussion mortar and further ground in an agate mortar unt1l the powder passed a 200-mesh $(74 \mu)$ sieve.

$X$-ray powder diffraction patterns were obtained in 
TABLE II

DESCRIPTION OF MIUERKLS

\begin{tabular}{|c|c|c|c|c|c|}
\hline Mineral & Formula 2 & subelass & (or Serios) & Source & $\begin{array}{l}\text { ASTM X-Ray PDF } 3 \\
\text { Reference; Hemarks }\end{array}$ \\
\hline Albite & $\mathrm{NaAlSI}_{3} \mathrm{O}_{8}$ & Tektosilicate & Plagloclase & $\begin{array}{l}\text { Bancroft, } \\
\text { Ontarto, Canada }\end{array}$ & $\begin{array}{c}9-466 \\
\text { Sowe discrepancy }\end{array}$ \\
\hline Andradite & $\mathrm{Ca}_{3} \mathrm{Fa}_{2}\left(\mathrm{SIO}_{4}\right)_{3}$ & Mesos1l1cate & Garnet & $\begin{array}{l}\text { Eagle Kts., } \\
\text { R1verside Co., California }\end{array}$ & Good agreement \\
\hline Muscovite & $\mathrm{KAl}_{2}\left(\mathrm{ALSI}_{3} \mathrm{O}_{10}\right)(\mathrm{OH})_{2}$ & Phyllosillcate & Mied & $\begin{array}{c}\text { Spruce P1ne, } \\
\text { Litchell Co., N. } C_{\text {a rolina }}\end{array}$ & Some $\begin{array}{l}\text { d1 screpancy } \\
\text { S-0263 }\end{array}$ \\
\hline Pyrophyllite & $\mathrm{Al}_{2} \mathrm{Si}_{4} \mathrm{O}_{10}(\mathrm{ClI})_{2}$ & Phyllosillcato & $-\infty$ & $\begin{array}{l}\text { Tres Cerritos } \\
\text { Mariposa Co., Calfrornia }\end{array}$ & Some $\begin{array}{l}2-0613 \\
\text { discrepancy }\end{array}$ \\
\hline Talc & $\mathrm{Hg}_{3} \mathrm{Si}_{4} \mathrm{O}_{10}(\mathrm{OH})_{2}$ & Phyllosillcate & $-\infty$ & Unknown ${ }^{2}$ & $\begin{array}{c}23-558 \\
\text { GeneraI agreament }\end{array}$ \\
\hline Mollastonlte & $\mathrm{CaS}_{3} \mathrm{O}_{3}$ & Inos111cate & Pyroxenold & $\begin{array}{l}\text { Calico, } \\
\text { San Bernadino'co., Calif. }\end{array}$ & $\begin{array}{c}10-487 \\
\text { General agreement }\end{array}$ \\
\hline
\end{tabular}

1 These forgulas represent hypothotical "1deal" minerals in which ion substitution does not occur; in reality, this is rarely the case.

2 It was intended to study the mineral tremol1te here. The mineral which was ordered was lablod tremolite and its source was listed as San Jacinto vit., Riverside Co, California. Ilowever, the mineral was apparentiy misidentified, since $x$-ray and infrared data sho: conclusively that is was actually talc.

3 The ASTM $x$-ray pdp references 11 sted here are those which best agree with the $x$-ray patterns obtained for the minerals used in this work. The remarks refer to comperisons of the patterns. Both the ASTu patterns and those obtained in this work are tabulated in Appendix $B$. 
order to verify that the minerals were properly identified and reasonably pure. Since a variety of methods are used to estimate line intensities, and since some minerals studied here are known to exhibit varying degrees of substitution depending upon their origin (e.g., albite of the plagioclase series), most of the powder patterns obtained in this work do not agree exactly with those published in the ASTM file. For this reason, the $x$-ray data for the minerals used in this study are listed in Tables B-I through B-6, Appendix B. The ASTH powder patterns best agreeing with the lattice spacings and line intensities found in this work are also included in these tables. To further verify that the minerals were properly identified, infrared spectra were compared with published spectra (20); good agreement was found for all six minerals.

The $x$-ray powder diffraction pattern of the wollastonite, $\mathrm{CaSiO}_{3}$, used in this work exhibits lines at $\mathrm{d}=4.247$, $3.320,1.811$, and $1.537 \AA$ suggesting that small amounts of quartz might be present (see Table B-6, Appendix B). Quartz contamination of wollastonite is not uncommon. In order to show conclusively that the mineral contained quartz, an $x$-ray powder pattern of a silica resldue recovered after dissolving the wollastonite in concentrated hydrochloric acid w as obtained and found to be identical to ASTM 5-0490, the ponder pattern of $\alpha$-quartz. Since pure wollastonite dissolves in concentrated acids to form only amorphous silica, 
the quartz had to be present originally. An attempt to remove the quartz from the wollastonite by a heavy liquid density separation was unsuccessful; apparently the densities of the two minerals ( $\rho=2.65$ and 2.9 respectively) are so similar, that the techniques used in this work were inadequate. However, a small quantity of magnetite, $\mathrm{Fe}_{3} \mathrm{O}_{4}$, separated from the wollastonite.

A density separation performed on andradite, $\mathrm{Ca}_{3} \mathrm{Fe}_{2}\left(\mathrm{SiO}_{4}\right)_{3}$, yielded only magnetite and andradite itself. If quartz or amorphous silica were present, they should have separated since their densities are considerably less than that of andradite. The $x$-ray powder pattern of the andradite used in this work (see Table B-2, Appendix B) agrees very well with ASTM 10-288 and does not indicate the presence of any quartz. The mineral did, however, contain considerably more magnetite than did the wollastonite mineral. Still, the quantity of magnetite was small and the $x-r a y$ pattern does not reveal its presence.

It was possible to separate trace quantities of magnetite from the other four minerals by means of a magnet, and the $x$-ray powder pattern of pyrophyllite, $\mathrm{Al}_{2} \mathrm{Si}_{4} \mathrm{O}_{10}(\mathrm{OH})_{2}$, reveals the presence of a small amount of quartz (see Table B-4, Appendix B).

\section{Initiation of Reactions}

A pH 4.0 buffer solution was prepared by dissolving 
$16.5 \mathrm{ml}$ of glacial acet1c acid and $4.1 \mathrm{~g}$ of sodium acetate in $500 \mathrm{ml}$ of delonized water. The pH was measured and adjusted to 4.0 by adding $0.1 \mathrm{~N}$ sodium hydroxide. A pH 10.0 buffer solution was prepared by dissolving $9.0 \mathrm{~g}$ of sodium bicarbonate along with $5.3 \mathrm{~g}$ of sodium carbonate in $500 \mathrm{ml}$ of delonized water. The $\mathrm{pH}$ was adjusted to 10.0 with $0.1 \mathrm{~N}$ sodium hydroxide.

Two sets of reaction mixtures were prepared in a $n i-$ trogen atmosphere:

Set 1. Quantities of albite, andradite, muscovite, pyrophyllite, talc and wollastonite such that 2.08 mmoles of silicon would be present (the quantities were based on the ideal formulas listed in Table II) were introduced into 50ml erlenmeyer flasks along w1th 6.2 mmoles $(0.69 \mathrm{~g})$ of practical grade catechol. The ratio of catechol to sillcon was $3: 1$. The flasks nere fitted with one-hole rubber stoppers Into which short lengths of pyrex tubing were inserted. Rubber serum caps were fitted to the tubing and then each Plask was swept with nitrogen for twenty minutes; nitrogen entered and departed through syringe needles inserted into the serum caps. Next, $25.0 \mathrm{ml}$ of $\mathrm{pH} 10.0$ buffer solution was introduced into each flask by means of a hypodermic syringe. Two additional reactions with pyrophylite and wol-

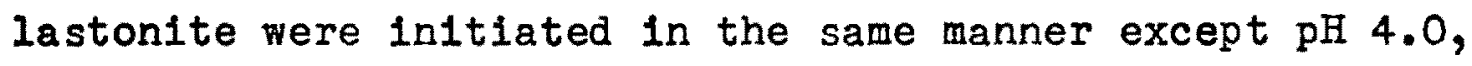
Instead of $\mathrm{pH}$ 10.0, buffer solution was introduced. After about twenty four hours, the six reaction mix- 
tures buffered at pH 10.0 began to develop a red-brown color while the $\mathrm{pH} 4.0$ reaction mixtures began to develop a violet color. After a couple of months, the reaction mixtures buffered at $\mathrm{pH} 10.0$ darkened. Apparently the basic catechol solutions were oxidizlng--quite likely because air leaked into the flasks, but possibly, since each mineral contained traces of magnetite, $\mathrm{Fe}_{3} \mathrm{O}_{4}$, because iron(III) might have been reduced to iron(II). The eight Set 1 reaction mixtures were set aside for a total of thirteen months.

Set 2. Th1s set of reactions was carried out with albite, andradite, muscovite, talc and wollastonite--pyrophyllite was excluded. The same quantities of starting materials were used here as in Set 1. Catechol and mineral were introduced into 100-mI round bottom flasks to which side arms fitted with serum caps were attached. A reflux condenser connected by rubber tubing to a bubbler trap was fitted to the neck of each flask. Nitrogen was passed through each flask via a syringe needle inserted into the serum cap. After purging for twenty minutes, $25.0 \mathrm{ml}$ of pH 10.0 buffer solution was introduced. Each reaction mixture was then refluxed for six hours under a slow steady stream of nitrogen.

During the reflux period, the reaction mixtures developed a red-brown color. After refluxing, the five flasks were allowed to cool, then were stoppered and set aslde for thirteen months. These reaction mixtures appeared to have 
been protected from the atmosphere better than those of Set 1 ; oxidation was not as noticeable.

\section{Treatment of Reaction Mixtures}

Set 1. When thirteen months had passed (thirteen months was a convenient, and not necessarily important, period of time), each reaction mixture in Set 1 was suction filtered under nitrogen. The residues were washed with water followed by acetone and allowed to dry in the atmosphere. Then they were melghed. The weights obtained are reliable only to about $\pm 5 \mathrm{mg}$ since the residues were not collected very quantitatively.

The filtrates from Set 1 were treated with $15.0 \mathrm{ml}$ of $1.0 \mathrm{HI}$ guanidinium hydrochloride, $\left(\mathrm{H}_{2} \mathrm{~N}\right)_{2} \mathrm{C}=\mathrm{NH} \cdot \mathrm{HCl}$, which was introduced with a hypodermic syringe. After a few minutes, precipitates began to form in the filtrates obtained from the $\mathrm{pH} 10.0$ reaction mixtures which originally contained wollastonite, pyrophyllite and albite. The precipitates were filtered under nitrogen, washed with small portions of cold water, dried in a vacuum and welghed. The filtrates from the $\mathrm{pH} 10.0$ muscovite, andradite and talc reaction mixtures were badly oxidized and no precipitates were obtained. Nor did the filtrates from the $\mathrm{pH} 4.0$ wollastonite and pyrophyllite reaction mixtures yield precipitates.

Set 2. Precipitate formation upon addition of guanidinium ions to the filtrates of the $\mathrm{pH} 10.0$ wollastonite, 
pyrophyllite and albite reaction mixtures of Set 1 implied that these three minerals react $w 1$ th catechol. Therefore, It was only necessary to treat the muscovite, andradite and talc reaction mixtures of Set 2. After filtering and introducing guanidinium hydrochloride, just as was done for Set 1 , precipltates formed in all three filtrates. These were collected and treated, as were the reaction residues, in the same way that they were for set 1.

\section{RESULTS}

Table III sumarizes the results of this study. Infrared spectra showed conclusively that the precipitates recovered by treating the filtrates with guanidinium ions were, in all six cases, the guanidinium salt of the catecholsilicon complex, $\left[\left(\mathrm{H}_{2} \mathrm{~N}\right)_{2} \mathrm{C}=\mathrm{NH}_{2}\right]_{2}\left[\mathrm{Si}(\mathrm{Cat})_{3}\right] \cdot \mathrm{XH}_{2} \mathrm{O}$. Infrared spectra also revealed that reaction residues with the exception of those collected from reactions with wollastonite consisted mainly of unreacted starting material.

$\mathrm{X}$-ray powder diffraction patterns of the residues obtained from the $\mathrm{pH} 10$ albite, andradite, muscovite, talc and pyrophylite reaction mixtures are compared with correspondIng starting mineral and ASTM powder patterns in Tables B-1 through B-5, Appendix B. A diffractometer was used to obtain the powder patterns of the original minerals, whereas the patterns of the residues were viewed on photographic filos. Diffractometer line intensities fali off rather rap- 
THats 311

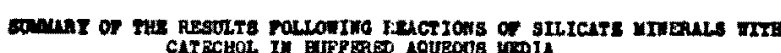

\begin{tabular}{|c|c|c|c|c|c|c|c|c|}
\hline \multirow{2}{*}{ utmoral } & \multirow{2}{*}{$\begin{array}{l}\text { pli of } \\
\text { Renetion } \\
\text { uixture }\end{array}$} & \multirow{2}{*}{ 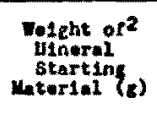 } & \multirow{2}{*}{$\begin{array}{c}\text { Wolght of } 3 \\
\text { Ronlduo } \\
(x)\end{array}$} & \multirow{2}{*}{ 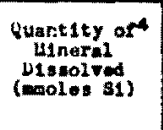 } & \multicolumn{3}{|c|}{ Restdus } & \multirow{2}{*}{ 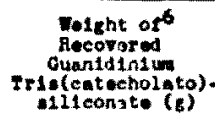 } \\
\hline & & & & & 1.R. & L-Ray pops, & Comments & \\
\hline $\begin{array}{l}\text { Albit: } \\
\text { mansi }\end{array}$ & 10.0 & 0.2828 & 0.148 & 0.40 & Albst. & $\begin{array}{l}\text { Albite } \\
\text { (Tablo B-1) }\end{array}$ & $\begin{array}{l}\text { The pdp genareily agreos } \\
\text { with that of the atarting } \\
\text { al oferal. }\end{array}$ & $(0.506$ manoles) \\
\hline 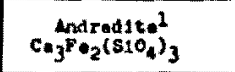 & 10.0 & 0.3537 & 0.318 & 0.22 & sodradite & $\begin{array}{l}\text { Ardradito } \\
\text { (Tablo B-2) }\end{array}$ & $\begin{array}{l}\text { Tho pip acteas with that } \\
\text { of the starsine einerai. }\end{array}$ & $(1.1055$ w0.5010s) \\
\hline 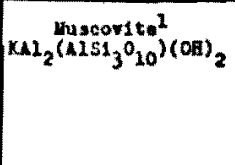 & 10.0 & 0.2756 & 0.222 & 0.40 & Uuseovite & $\begin{array}{l}\text { unscor1to } \\
\text { (Tathe a-j) }\end{array}$ & 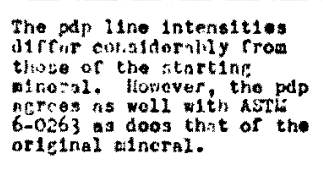 & $\left(2.010^{0.454}\right.$ ando1...) \\
\hline$u_{x_{3}} \operatorname{sic}_{4}^{2010_{20}^{1}}$ & 10.0 & 0.2117 & 0.183 & 0.30 & telo & 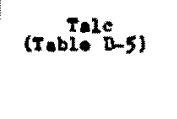 & 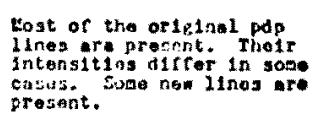 & $\left(0.685^{0.3362}=0\right.$ \\
\hline \multirow[t]{2}{*}{ 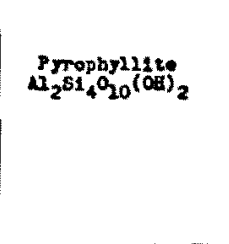 } & 20.0 & 0.1876 & 0.263 & 0.27 & Prophyllit. & 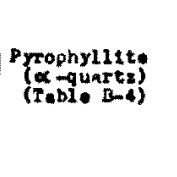 & 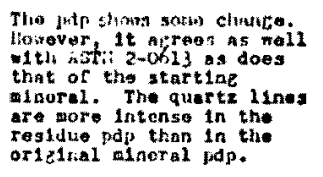 & $\left(0.633^{0.3095}\right.$ \\
\hline & 4.0 & 0.2868 & 0.165 & -- & P yrophylitse & - & A pdp uss not run. & None \\
\hline \multirow{2}{*}{$\begin{array}{l}\text { molleatonitu } \\
\text { Casto }_{3}\end{array}$} & 10.0 & 0.2413 & 0.205 & $\cdots$ & $\begin{array}{l}\mathrm{Calc1t} \\
\mathrm{Cesco}_{3} ;\end{array}$ & 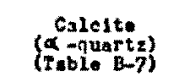 & 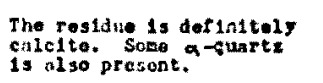 & $\left(0.508^{0.2492}=01010.4\right)$ \\
\hline & 4.0 & 0.2432 & 0.150 & -- & silte: & 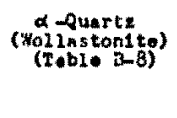 & 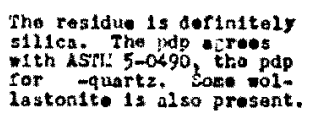 & nose \\
\hline
\end{tabular}

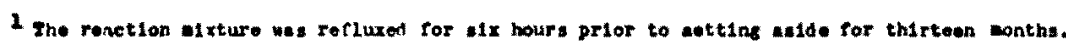

2 these wights correspond to 2.08 moles of illicon.

3 The residues wore not eollected very quant1tatively. These numbors ere probably not better than \pm 5 ec.

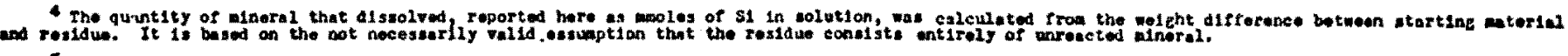

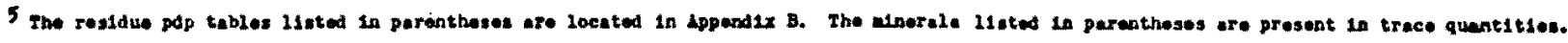

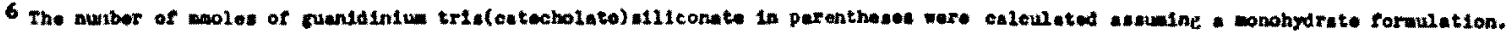


Idly with Increasing angle (1.e., decreasing d-spacing) and the intensities of lines viewed on films were only visually estimated; consequently, comparisons of intensities can only be expected to be qualitative. Nevertheless, the $x$-ray, I1ke the Infrared, data show that these five pH 10 reaction residues consisted mainly of unreacted starting mineral. However, they also show that at least some mineral alteration may have occurred--especially with muscovite and to a lesser extent with talc and pyrophyllite. That alteration may have occurred is inferred from the fact that in some cases line intensities have changed drastically, and in other cases new lines have appeared. None of the new lines were Identified and the investigation of the residues was not further pursued. An x-ray powder pattern of the $\mathrm{pH} 4$ pyrophylite reaction residue was not obtained.

Examination of the residues obtained from the $\mathrm{pH} 4$ and pH 10 reaction mixtures of wollastonite revealed that little, If any, of the original mineral remained. Calcite, $\mathrm{CaCO}_{3}$, formed in the $\mathrm{pH} 10$ reaction mixture (a carbonate buffer), and silica formed in the $\mathrm{pH} 4$ mixture. The $x$-ray pattern of the pH 10 residue (Table B-7, Append1x B) shows some weak quartz lines along with the calcite lines, and the pattern of the $\mathrm{pH} 4$ residue (Table B-8, Append $1 \times$ B) shows quartz Iines only.

\section{DISCUSSION}

The data in Table III reveal that in every case the 
original quantity of mineral provided 2.08 mmoles of silicon, the amounts of silicon recovered in the form of the guanidinium salt ranged from 0.506 to 1.105 mmoles (assuming that the salt is a monohydrate), and the weight differences between residues and mineral starting materials ranged from 24 to $54 \mathrm{mg}$. Assuming that every residue consisted of unreacted starting mineral, in each case the amount of mineral which reacted does not account for all of the product obtalned (compare columns 5 and 9, Table III).

It is not possible, on the basis of the work performed here, to rationalize such an anomaly with any certainty. Nevertheless, reaction residues might have contained quant1tles of water--either surface adsorbed or incorporated in structurally disrupted outer margin alteration layers with the original mineral structure preserved in the inner zone-which would have the effect of minimizing the apparent extent of mineral dissolution. Such an explanation is not inconsistent with the $x$-ray data which, as was pointed out earlier, reveals that with each residue except those obtained from wollastonite reaction mixtures some alteration may have occurred even though the original mineral is st1ll present. Another explanation for the fact that the apparent quantity of mineral which dissolved does not account for all of the product obtained lies in considering the glass reaction vessels as sources of silicon. Weiss (7) has shown that the reaction rate of catechol with various forms of 
silica decreases drastically as the specific surface area decreases. The specific surface area of the 50-ml glass reaction ressels used in this work is minute compared to that of the finely divided minerals, and no etching of vessels was detected. Nevertheless, alkaline solutions are known to attack glass, and, since a control reaction ras not run, such a possibility cannot be ignored.

Regardless of what the explanation might be, this study clearly reveals that in the presence of catechol at least some mineral dissolves; in the case with wollastonite, most if not all of the mineral dissolves; and as each mineral dissolves, the catechol-silicon ester forms (1.e., except in acid media).

Catechol will react slowly with finely divided quartz. Helss (7), for example, demonstrated that after sixty days, approximately $32 \%$ of a sample of quartz particles which were smaller than $7 \mu$ dissolved in a "concentrated" catechol solution at $\mathrm{pH}$ 8.2. Larger particles of quartz react at a much slower rate.

It was mentioned earlier that the wollastonite and pyrophylite used in these reactions contained small amounts of quartz and that the andradite dia not contain any detectable quantities. Although the alkite, muscovite and talc used here might have contained trace quantities of quartz, $x$-ray powder patterns do not reveal its presence. The $x$-ray powder patterns of the pyrophylite and wol- 
lastonite reaction residues revealed quartz lines which were even more intense than the corresponding lines in the patterns of the original minerals. The conclusion is that the catechol-silicon complex isolated in these reactions originated primarily from dissolution of the minerals themselves rather than from reactions with quartz contaminants.

Wollastonite dissolves in both concentrated acid and concentrated base solutions with the separation of silica. It has been reported $(21, \mathrm{p} .357)$ that wollastonite is soluble in water to the extent of $0.01 \mathrm{~g} / 1$; how long it takes to attain equilibrium was not mentioned. Although the conditions under which the reactions between catechol and wollastonite were carried out were quite mild, the mineral st11l dissolved almost completely.

In the presence of catechol at $\mathrm{pH} 10$, silica did not form--the complex did. And, in the carbonate-bicarbonate buffer solution, calcium precipitated as calcite:

$\mathrm{CaSlO}_{3}+3 \mathrm{H}_{2} \mathrm{Cat} \stackrel{\mathrm{CO}_{3}^{2-}}{\longrightarrow} \mathrm{SICat}_{3}{ }^{2-}+\mathrm{CaCO}_{3} \downarrow+3 \mathrm{H}_{2} \mathrm{O}$ (Wollastonite) (Calc1te)

Baumann (10) showed, in connection with some quite. thorough studies of the three-way equilibrium between silica, $\mathrm{SiO}_{2} \cdot \mathrm{XH}_{2} \mathrm{O}$, silicic acid, $\mathrm{Si}(\mathrm{OH})_{4}$, and the catechol-silicon complex, SiCat ${ }^{2-}$, that at $\mathrm{pH} 4$ the concentration of complex is extremely small $\left(\sim 10^{-8} \mathrm{M}\right)$ when the catechol concentration is only 0.25 in as 1 t was with the reactions carried out in this work. His rindings are consistent with the fact 
that the guanidinium salt of the complex, as well as other salts, decompose in acid media to form silica. So the recovery of the complex from the $\mathrm{pH} 4$ wollastonite reaction mixture was not realized; however, silica formed:

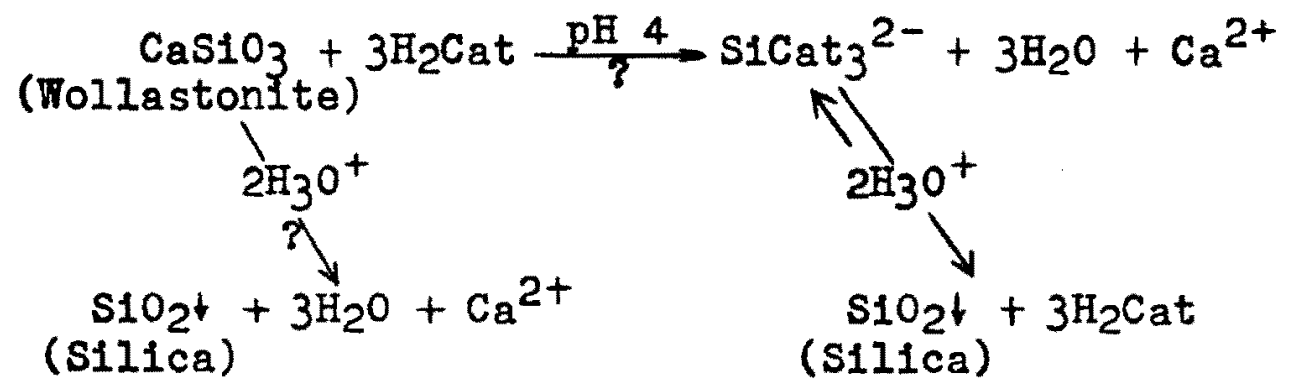

An Important question is whether catechol actually effected the dissolution of the minerals studied in this work, or whether they would have dissolved even if catechol had not been present. Mellor (21) indicates that andradite, albite and talc are insoluble in concentrated acid solutions, but that pyrophyllite is slightly affected by concentrated hydrochloric acid. He also points out that pyrophyllite is slightly attacked by sodium carbonate solutions. However, most reports dealing with the dissolution of the minerals studied here focus on hydrothermal decomposition. It may be considered highly probable but, since control reactions were not run, not absolutely conclusive that catechol played the major role in dissolving these silicate minerals. This conclusion is supported by the fact that even muscovite, which is extremely persistent in weathering environments and was reported $(2 l, p .618)$ to be insoluble in carbonated water even 
after one year, reacted to form the complex.

The reaction mixtures were not adequately protected from the atmosphere in this experiment. The fact that catechol-silicon esters were not recovered from the oxidized muscovite, andradite and talc reaction mixtures of Set 1 , yet were from the better protected set 2 reaction mixtures, supports this statement. Negative results for reactions undertaken with the minerals diopside, white beryl, kaolinite, orthoclase and zircon mere not described since, with the exception of kaolinite, serlous oxidation of the reaction mixtures rendered such results inconclusive. It is not unlikely that some of these minerals will also react with catechol.*

* Recently, the catechol-silicon complex was 1solated as the guanidinium salt from a reaction between catechol and diopside, $\mathrm{CaMgS12} \mathrm{O}_{6}$, in this laboratory by Boonthong Poocharoen. 
IV. REACTIONS BETWEEN SILICATE MINERALS

AND CATECHOL IN UNBUFFERED

AQUEOUS WEDIA

\section{INTRODUCTION}

It was shown in Part III that aqueous catechol solutions buffered at $\mathrm{pH} 10 \mathrm{w1Il}$ attack the silicate minerals albite, andradite, muscovite, pyrophyllite, talc and wollastonite to form a catechol-silicon complex. Since the environmental $\mathrm{pH}$ represents mainly the effect rather than the cause of chemical weathering (12, p.vii), reactions described in this section were carried out in unbuffered aqueous media with the $\mathrm{pH}$ monitored. The purpose was to react minerals (i.e., wollastonite, andradite, talc, white beryl and dlopside) under pH conditions satisfying natural environmental criteria, to react them in quantities sufficient to dispel doubts that catechol effected dissolution might be insignificant, and to further show that the minerals themselves react rather than reaction vessel surfaces or contaminants. In addition, an effort to isolate a possible calcium salt of the catechol-silicon complex, $\mathrm{Ca}[\mathrm{Si}$ (Cat) 3 , from a reaction mixture of catechol and wollastonite, $\mathrm{CaSiO}_{3}$, is described.

\section{EXP ERIMENTAL}

Description of Minerals 
The wollastonite used in these reactions was ground to pass a 325 -mesh $(43 \mu)$ sleve; the andradite, talc, white beryl and diopside were ground to pass a 200-mesh $(74 \mu)$ sleve. The $x$-ray powder diffraction patterns of the andradite, talc and wollastonite are shown in Tables B-2, B-5 and B-6, Appendix B, respectively. The wollastonite contains a small amount of quartz. The powder pattern of the white beryl, $\mathrm{Be}_{3} \mathrm{Al}_{2}\left(\mathrm{SlO}_{3}\right)_{6}$, used here agrees well with ASTM 9-430. The diopside, $\mathrm{CaMgSI}_{2} \mathrm{O}_{6}$, powder pattern shows reasonable agreement with ASTH 11-654; a trace of quartz might be present. It was possible to remove traces of magnetite, $\mathrm{Fe}_{3} \mathrm{O}_{4}$, from all five of these minerals by means of a magnet.

Preparation of $\left[\left(\mathrm{H}_{2} \mathrm{~N}\right)_{2} \mathrm{C}=\mathrm{NH}_{2}\right]_{2}\left[\mathrm{Si}(\mathrm{Cat})_{3}\right] \cdot \mathrm{XH}_{2} \mathrm{O}$ from Wollastonite

Fethod 1. $1.5 \mathrm{~g}$ of catechol, $0.5 \mathrm{~g}$ of wollastonite, $\mathrm{CaSiO}_{3}$, and $1.0 \mathrm{~g}$ of guanidinium hydrochloride, $\left(\mathrm{H}_{2} \mathrm{M} / 2 \mathrm{C}=\mathrm{NH} \cdot \mathrm{HCl}\right.$, were introduced into a 125-ml erlenmejer flask. The flask was purged with nitrogen and $50 \mathrm{ml}$ of water was added. After about twenty four hours, long needle-like crystals of $\left[\left(\mathrm{H}_{2} \mathrm{~N}\right)_{2} \mathrm{C}=\mathrm{NH}_{2}\right]_{2}\left[\mathrm{Si}(\mathrm{Cat})_{3}\right] \cdot \mathrm{XH}_{2} \mathrm{O}$ began to grow upward from the unreacted wollastonite. However, the guanidinium salt has not been recrystallized in this work and so the preparation described below (Wethod 2), in which the product is free of mineral, is typical of several reactions which were carried out.

Method 2. A reaction mixture consisting of $14.72 \mathrm{~g}$ of 
catechol and $3.89 \mathrm{~g}$ of wollastonite in $400 \mathrm{ml}$ of water was refluxed under nitrogen for ninety hours. Occaslonally durIng the reflux period, the reaction mixture was cooled, a calomel-glass combination electrode was inserted into the solution, and the $\mathrm{pH}$ was checked; it remained at 7.0 throughout the course of the reaction. After refluxing, the unreacted mineral was filtered off under nitrogen--2l: $0.83 \mathrm{~g}$ corresponding to 7.2 mmoles) of the wollastonite dissolved-and $50 \mathrm{ml}$ of $1.0 \mathrm{M}$ guanidinium hydrochloride was introduced into the dark red-brown filtrate. The precipitate which formed was filtered, washed with several portions of cold I $M$ amonium hydroxide and dried to constant weight in a vacuum at room temperature. The yield was $2.16 \mathrm{~g}$ (4.5 mmoles), or $63 \%$ with respect to the quantity of mineral which dissolved. Infrared, $x-r a y, n m r$ and analytical data confirmed that the precipitate, which had a slight pink tinge due to a trace of iron impurity, was guanidinium tris(catecholato)siliconate.

Preparation of $\left[\left(\mathrm{H}_{2} \mathrm{~N}\right)_{2} \mathrm{C}=\mathrm{NH}_{2}\right]_{2}\left[\mathrm{SI}(\mathrm{Cat})_{3}\right] \cdot \mathrm{XH}_{2} \mathrm{O}$ from Andradite

A reaction mixture consisting of $20.0 \mathrm{~g}$ of catechol and $5.14 \mathrm{~g}$ of andradite in $350 \mathrm{ml}$ of water was refluxed under nitrogen for 142 hours. Prior to refluxing, the $\mathrm{pH}$ of the reaction mixture was 6.8. After the reflux period, the $\mathrm{pH}$ was found to be 6.0 . Initially, the reaction mixture was a red-brown color but became dark violet as the $\mathrm{pH}$ dropped. 
Following the filtration of the reaction mixture--11\% $(0.56 \mathrm{~g}$, corresponding to 3.3 moles of silicon) of the andradite dissolved--90 ml of 1.0 Ul guanidinium hydrochloride was added to the filtrate. Whereas a precipitate began to form within a few minutes after the introduction of guanidinium Ions to the filtrate obtained from the wollastonite reaction mixture, such wasn't the case with the andradite reaction. When no precipitate was observed, the pH of the filtrate was ralsed to 7.5 by adding $5 \mathrm{ml}$ of $1.0 \mathrm{~N}$ sodium hydroxide. Small lustrous red-violet crystals formed overnight. It is not known whether the addition of base was really necessary. After washing and then drying to constant weight, a light red-violet powder was left. X-ray and infrared data showed this powder to be guanidinium tris(catecholato)siliconate. A yield of $0.39 \mathrm{~g}(0.80$ mmoles $)$, or $24 \%$ with respect to the quantity of mineral which dissolved, was realized.

Reactions of Diopside, Talc and White Beryl with Catechol Reactions of catechol with diopside, talc and white beryl, which were initiated in a similar manner as the reaction of catechol with andradite, were unsuccessful. These three minerals did not dissolve to any significant extent. The hydrolyzed to form acld reaction mixtures (i.e., diopside, $\mathrm{pH}=5.1$; white beryl, $\mathrm{pH}=5.4$; talc, $\mathrm{pH}=5.6)$.

Preparation of an Unidentified Calcium Salt, Compound A, from irollastonite 
Method 1. $26.04 \mathrm{~g}$ of catechol and $4.61 \mathrm{~g}$ of wollastonite in $400 \mathrm{ml}$ of water was refluxed under nitrogen for 157 hours. During the reflux period, the $\mathrm{pH}$ of the reaction mixture ras malntained between 7.5 and 8.0 by adding about $8 \mathrm{ml}$ of $1.0 \mathrm{~N}$ sodium hydroxide. When the reaction mixture had cooled and sat for a few days, aggregates of dark redviolet crystals, Compound A, formed. The crystals were mixed with unreacted wollastonite.

Lethod 2. The 1dentical compound was prepared by refluxing $11.0 \mathrm{~g}$ of catechol and $5.0 \mathrm{~g}$ of wollastonite in $65 \mathrm{ml}$ of water. Under these conditions, the "apparent $\mathrm{pH}$ " of the reaction mixture, as determined using a calomel-glass electrode, remained at 7.5 without adding base. Dark red-violet crystals began to grow in the hot reaction mixture after a fev days of refluxing. After refluxing for twenty days, a portion of one of the crystals (the crystals were very large by then) was removed from the cooled reaction mixture, washed off with a little cold water and dried to constant weight in a vacuum at room temperature. As it dried, it disintegrated to a light pink powder.

Anal. Found: $\mathrm{C}, 51.50 ; \mathrm{H}, 4.74 ; \mathrm{S1}, 7.38,8.26$; $\mathrm{Ca}, 8.49,8.15$. The $\mathrm{x}$-ray powder diffraction pattern of Compound $A$ is shomn in Table C-1, Append1x C. The infrared spectrum is shown in Figure C-1, Appendix C, and the nmr spectrum in deuterium oxide is shown in F1gure C-3. The $\mathrm{nmr}$ spectrum in DMSO (not shown), though poorly resolved, 
reveals a peak at $T 3.33 \mathrm{ppm}$ and another at $\uparrow 3.64 \mathrm{ppm}$. Compound $A$ is only slightly soluble in water and even less soluble in DMSO. If allowed to stand in ethyl ether for about one half hour, it forms a sticky green resinous mass which disintegrates to a green powder when the ether evaporates. Then $d r y$, it is stable in the atmosphere for short periods of time. However, after two days of exposure to air, the light pink powder begins to develop a greyish cast.

\section{DISCUSSION OF RESULTS}

\section{The Dissolution of Silicate Minerals}

The observed losses in weight of mineral starting materials (21\% of the original $3.89 \mathrm{~g}$ of wollastonite and $11 \%$ of the original $5.14 \mathrm{~g}$ of andradite dissolved) resulting from treatment with aqueous catechol shows that the minerals themselves were reacting rather than impurities or glass surfaces of reaction vessels (1.e., it has been shown that the andradite contained no detectable quantities of silica of any kind).

Two main factors contributing to the greater effectiveness exhibited by catechol in attacking wollastonite as compared to the other minerals described in this section are belleved to be: The wollastonite had a greater specific surface area since the particle size was $\leq 43 \mu$ whereas the other minerals were ground to $\leq 74 \mu$; and the wollastonite 
reaction mixture remained neutral wile the other minerals hydrolyzed to form acld solutions--a factor which might explain why the catechol-silicon complex was not isolated from the talc, white beryl and dlopside reaction mixtures which experienced $\mathrm{pH}$ drops to about 5.5. The fact that talc and diopside react with catechol under more favorable conditions (1.e., higher $\mathrm{pH}$ and/or catechol concentration) has already been established.

Balanced reactions describing the dissolution of the slilcate minerals studied in this work cannot, from these studies, be written with certainty. However, the fact that neutral or slightly acid solutions are formed can be rationalized in a qualitative manner.

Consider, for example, the dissolution of andradite in aqueous catechol to form a pH 6 solution. The balanced reaction cannot be written since the nature of the cationic specles is highly speculative. Therefore, the reaction will be written in a stepwise manner with andradite dissolving to form the catechol-silicon complex,

$\mathrm{Ca}_{3} \mathrm{Fe}_{2}\left(\mathrm{SiO}_{4}\right)_{3}+9 \mathrm{H}_{2} \mathrm{Cat} \longrightarrow 3 \mathrm{Ca}^{2+}+2 \mathrm{Fe}^{3+}+3 \mathrm{Si}(\mathrm{Cat})_{3}^{2-}+6 \mathrm{OH}^{-}+6 \mathrm{H}_{2} \mathrm{O}$ (Andradite)

and then the ultimate fate of $\mathrm{Ca}^{2+}$ and $\mathrm{Fe}^{3+}$ will be considered. Since both $\mathrm{Ca}^{2+}$ and $\mathrm{Fe}^{3+}$ hydrolyze in water to form acid solutions, the $\mathrm{OH}^{-}$ions shown to form in the above reaction would immediately be consumed--explaining in part why an 
acid solution actually formed.

e.g.,

$$
\mathrm{Ca}^{2+}+\mathrm{OH}^{-} \rightleftarrows \mathrm{CaOH}^{+}
$$

However $\mathrm{Fe}^{3+}$, besides hydrolyzing to form $\mathrm{Fe}(\mathrm{OH})^{2+}, \mathrm{Fe}(\mathrm{OH})_{2}^{+}$, or perhaps even precipitating as $\mathrm{Fe}(\mathrm{OH})_{3}$ (no attempt was made to detect $\mathrm{Fe}(\mathrm{OH})_{3}$ in reaction residues), is also very likely reacting with catechol to form a complex.

In this work, mineral reaction mixtures were red-brown above $\mathrm{pH} 6.5$ and violet below this value, which is explained by Weinland (22) who found that deep red alkaline solutions of Iron and catechol contain $\mathrm{Fe}\left(\mathrm{Cat}_{3}{ }^{3-}\right.$, while violet acld solutions contain $\mathrm{Fe}(\mathrm{Cat})_{2}^{-}$. Also, traces of iron complex were present whenever $\left[\left(\mathrm{H}_{2} \mathrm{~N}\right)_{2} \mathrm{C}=\mathrm{NH}_{2}\right]_{2}\left[\mathrm{~S} 1(\mathrm{Cat})_{3}\right] \cdot \mathrm{XH}_{2} \mathrm{O}$ was 1solated from reactions of minerals with catechol. Iron, inherent in the mineral itself or present in an impurity (1.e., present as magnetite, $\mathrm{Fe}_{3} \mathrm{O}_{4}$ ), reacting with catechol would lower the $\mathrm{pH}$ of a reaction mixture.

e.g., $\quad \mathrm{Fe}^{3+}+2 \mathrm{H}_{2} \mathrm{Cat} \stackrel{\mathrm{pH} \leq 6.5}{\rightleftarrows} \mathrm{Fe}(\mathrm{Cat})_{2}^{-}+4 \mathrm{H}^{+}$

Description of Compound A

Quite possibly Compound $A$ is a mixture consisting mainly of $\mathrm{Ca}\left[\mathrm{SI}(\mathrm{Cat})_{3}\right] \cdot \mathrm{XH}_{2} \mathrm{O}$, but also containing $\mathrm{Ca}(\mathrm{HCat})_{2} \cdot \mathrm{XH}_{2} \mathrm{O}$ and some wollastonite, $\mathrm{CaSiO}_{3}$. That $\mathrm{Ca}\left(\mathrm{Si}(\mathrm{Cat})_{3}\right.$ ) should form under the reaction conditions employed in this work follows from the fact that the magnesium analog, $\mathrm{Mg}\left[\mathrm{SI}(\mathrm{Cat})_{3}\right]$, has 
been prepared under simllar circumstances.* However, cond1tions of high pH and high catechol concentration shown by Baumann (10) to favor catechol-silicon ester formation also favor formation of the metal catecholates (e.g., $\mathrm{Ca}(\mathrm{HCat})_{2}$ ) described by Scholder and Wolf (23). In this work it was found that when adding base to reaction mixtures of catechol and wollastonite in order to precipitate $\mathrm{Ca}\left[\mathrm{S} 1(\mathrm{Cat})_{3}\right]$, as the $\mathrm{pH}$ approached $9, \mathrm{Ca}(\mathrm{HCat})_{2} \cdot \mathrm{XH}_{2} \mathrm{O}$ precipitated exclusively. The rather large discrepancies between the two calcium and two silicon analyses which were performed on the same sample imply that the mixture, Compound $A$, is non-homogeneous--possibly because of occluded wollastonite, the presence of which is confirmed by the $x$-ray powder diffraction pattern of Compound A (Table C-1, Appendix C).

The Infrared spectrum of Compound A (FIgure C-1, Appendix $c$ ) exhibits several bands also seen in the spectrum of $\mathrm{Ca}$ (HCat) $2 \cdot \mathrm{XH}_{2} \mathrm{O}$ (Figure $\mathrm{C}-2$, Appendix $\mathrm{C}$ ), but those in the aromatic C-H in-plane bending region are particularly revealing: The absorption band at $9.10 \mu$ likely arises both from $\mathrm{Ca}(\mathrm{HCat})_{2} \cdot \mathrm{XH}_{2} \mathrm{O}$ and $\mathrm{Ca}\left[\mathrm{Si}(\mathrm{Cat})_{3}\right] \cdot \mathrm{XH}_{2} \mathrm{O}$, the band at $9.72 \mu$ from the former compound only, and the band at $9.85 \mu$ from the latter. That these absorption bands are not assoclated with catechol itself is clearly revealed by viewing a spec-

* Mr. Boonthong Poocharoen prepared $\mathrm{Kg}\left[\mathrm{S} 1(\mathrm{Cat})_{3}\right]$ in this laboratory from a synthetic magnesium silicate, $\mathrm{Hg}_{2} \mathrm{Si}_{3} \mathrm{O} \cdot \mathrm{g}_{2} \mathrm{\textrm {H } _ { 2 } \mathrm { O }}$. He also recovered a substance idertical to Compound $\mathrm{A}$ from a reaction mixture of diopside, $\mathrm{CallgSi}_{2} \mathrm{O}_{6}$, and catechol. 
trum of Compound A admittedly contaminated with catechol (Figure C-2, Appendix C) which shows an additional band at $9.59 \mu$ and a shoulder at $9.10 \mu$.

The nmr spectrum of a saturated solution of Compound A in deuterium oxide (Figure C-3, Appendix C) shows two phengl proton peaks. The one at $\uparrow 3.25 \mathrm{ppm}$ ( $\pi 3.64 \mathrm{ppm}$ in DusO) corresponds to the position of the phenyl proton peak of $\mathrm{Ca}$ (HCat) ${ }_{2} \cdot \mathrm{XH}_{2} \mathrm{O}$. The peak at $\uparrow 3.0 \mathrm{ppm}$ ( $\uparrow 3.33 \mathrm{ppm}$ in DMSO) possibly arises from the phenyl protons of $\mathrm{Ca}\left[\mathrm{Si}(\mathrm{Cat})_{3}\right] \cdot \mathrm{XH}_{2} \mathrm{O}$; although catechol, which could have formed as a hydrolysis product, exhibits an $\mathrm{A}_{2} \mathrm{~B}_{2}$ splitting pattern at about the same location. 


\section{REFEREMCES}

1. W. D. Evans, "The Organic Solubilization of minerals in Sediments," Advances in Organic Geochemistry. ed. U. Colombo and G. D. Hobson. New York: Pergamon Press, 1964.

2. R. K. Iler, The Collold Chemistry of Sillca and Silicates. Ithaca: Cornell University Press, 1955.

3. M. Ghassemi and R. F. Christman, Limnology and Oceanography, 13, 583-97(1968).

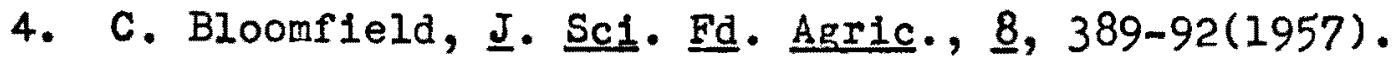

5. F. J. Hingston, Aust. J. So11 Res., 1, 63-73(1963).

6. A. Rosenhe1m, B. Ralbmann, and G. Schendel, Z. Anorg. Allgem. Chem., 196, 160-76(1931).

7. A. Weiss, G. Reiff, and A. Weiss, Z. Anorg. Allgem. Chem., 311, 151-79(1961).

8. A. Rosenheim and 0. Sorge, Ber., 53, 932-9(1920).

9. H. Bartels and H. Erlenmeyer, Helv. Chim. Acta., 47, $7-13(1964)$.

10. H. Baumann, Be1tr. Silikose-Forsch., S-Bd Grundfragen silikoseforsch., 4, 43-50(1960).

11. I. V. Tsygankov, Tr. Belorussk. Nauchn.-Issled. Inst. Rybn. Khoz., 3, 77-105(1960). CA 59:7237.

12. F. C. Loughnan, Chemical Weathering of the Sllicate Minerals. New York: Elsevier, 1969.

13. R. Hess, R. Bach, and H. Deuel, Experent1a, 16, 38-40 (1960).

14. M. H. Kononova, I. V. Aleksandrova, and N. A. Titova, Pochvovedenie, 1964, 1-12.

15. R. Slever and R. A. Scott, "Organic Geochemistry of Silica," Internat. Ser. of Honographs on Earth Sclences, Vol. 16, Organic Geochemistry. ed. I. A. Breger. New York: MacMllian, 1963. 
16. J. J. Flymn and F. P. Boer, J. Am. Chem. Soc., 21, 5756-61(1969).

17. D. T. Barnum, Inorg. Chem., 2, 1942-3(1970).

18. C. I. Frye, I. Am. Chem. Soc., 86, 3170-1(1964).

19. D. W. Barnum, "Reaction of Catechol with Silica and Silicic Acld in Aqueous Ammonia," Inorg. Chem., in press.

20. J. M. Hunt, W. P. Wisherd, and I. C. Bonham, Anal. Chem, 22, 1478-97(1950).

21. J. W. Mellor, A Comprehensive Treatise on Inorganic and Theoretical Chemistry, Vol. VI. London: Longmans, Green and Co., 1953.

22. R. F. Weinland and K. Binder, Ber., 45, 1113-24(1912).

23. R. Scholder and M. Wolf, Z. Anorg. Allgem. Chem., 210, 184-94(1933). 


\section{APPENDIX A}

X-RAY POWDER DIFFRACTION PATTERN, INFRARED AND NMR SPECTRA, AND EQUIVALENT CONDUCTANCE OF GUANIDINIUNA TRIS(CATECHOLATO) SILICONATE

A Perkin-Elmer 137 B INFRACORD spectrophotometer was used to obtain infrared spectra. The nmr spectrum vas obtained by using a Varian A-60 nmr spectrometer.

The powder diffraction pattern was measured with a General Electric XRD-5 $x$-ray spectrometer using a copper target and a nickel filter. I/Io = relative intensity on a scale running from 0 to $100 ; \mathrm{d} \&=$ distance, in angstrom units, between crystal planes. 
TABLB A-1

X-RAY POWDER DIFTRACTION PATTERN OF $\left.\left[\left(\mathrm{H}_{2} \mathrm{~N}\right)_{2} \mathrm{C}=\mathrm{NH}_{2}\right]_{2}[\mathrm{SI} \text { (Cat) })_{3}\right] \cdot \mathrm{XH}_{2} \mathrm{O}$

\begin{tabular}{|c|c|c|c|}
\hline \multicolumn{2}{|c|}{ Radiation: $\operatorname{CuK}_{\infty}$} & \multicolumn{2}{|c|}{$I / I_{0}:$ Diffractometer } \\
\hline $\begin{array}{r}0 \\
\mathrm{~d} \AA\end{array}$ & $I / I_{0}$ & $\underline{\mathrm{d}} \mathrm{A}$ & $I / I_{0}$ \\
\hline $\begin{array}{l}14.0 \\
13.4 \\
11.11 \\
10.04 \\
8.93 \\
8.04 \\
7.525 \\
6.992 \\
6.883 \\
6.627 \\
6.254 \\
5.712 \\
5.320 \\
5.166 \\
5.007 \\
4.805 \\
4.619 \\
4.525 \\
4.227 \\
4.101 \\
4.037 \\
3.864\end{array}$ & $\begin{array}{r}8 \\
6 \\
12 \\
100 \\
45 \\
84 \\
36 \\
27 \\
25 \\
24 \\
36 \\
4 \\
28 \\
54 \\
60 \\
14 \\
23 \\
17 \\
7 \\
100 \\
97 \\
15\end{array}$ & $\begin{array}{l}3.735 \\
3.682 \\
3.552 \\
3.477 \\
3.373 \\
3.312 \\
3.223 \\
3.118 \\
2.957 \\
2.887 \\
2.846 \\
2.572 \\
2.469 \\
2.348 \\
2.215 \\
2.023 \\
1.995 \\
1.940 \\
1.809 \\
1.760 \\
1.720\end{array}$ & $\begin{array}{r}14 \\
23 \\
30 \\
64 \\
27 \\
30 \\
14 \\
4 \\
10 \\
21 \\
18 \\
12 \\
8 \\
6 \\
7 \\
8 \\
9 \\
6 \\
6 \\
4 \\
8\end{array}$ \\
\hline
\end{tabular}




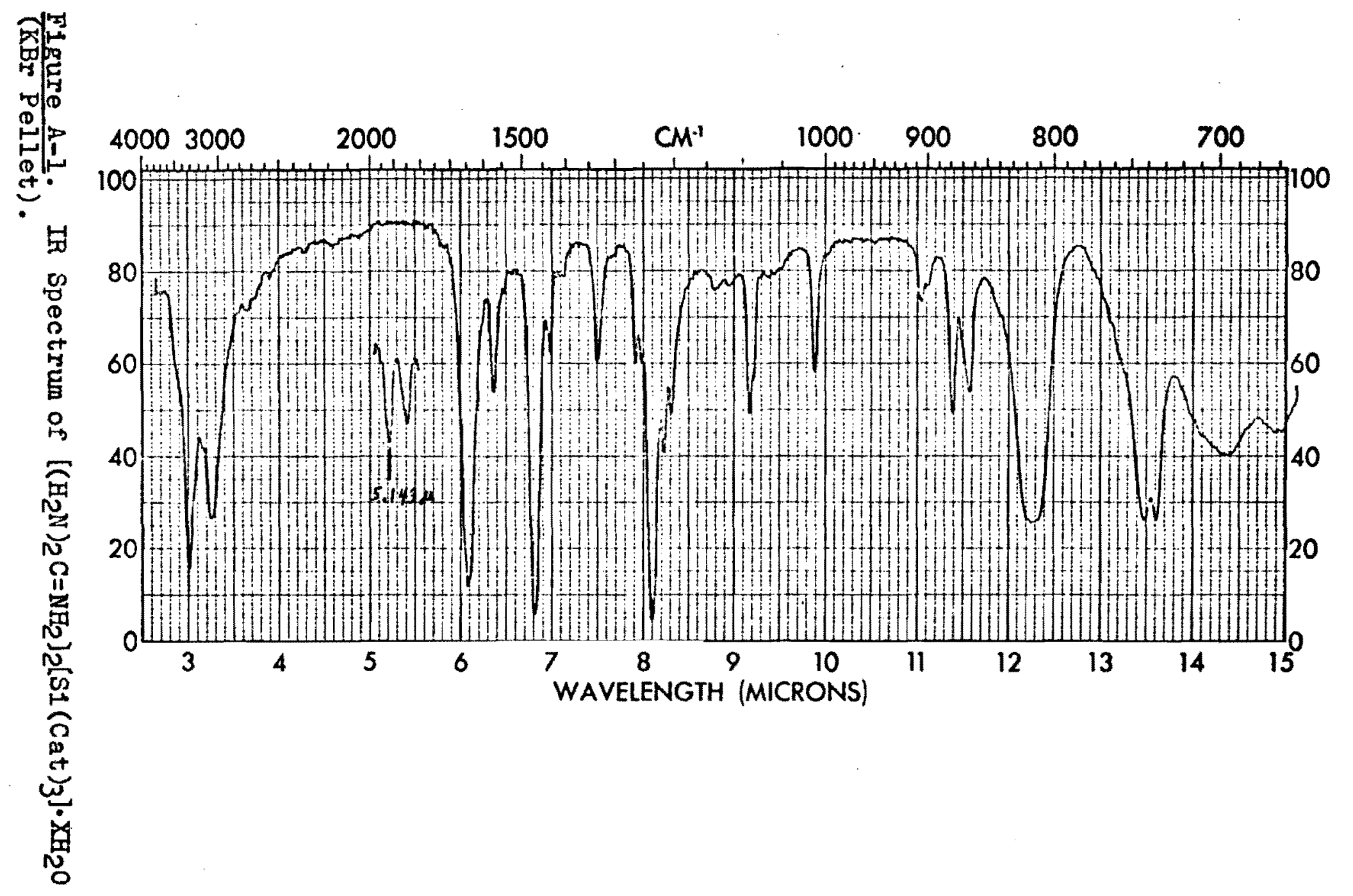




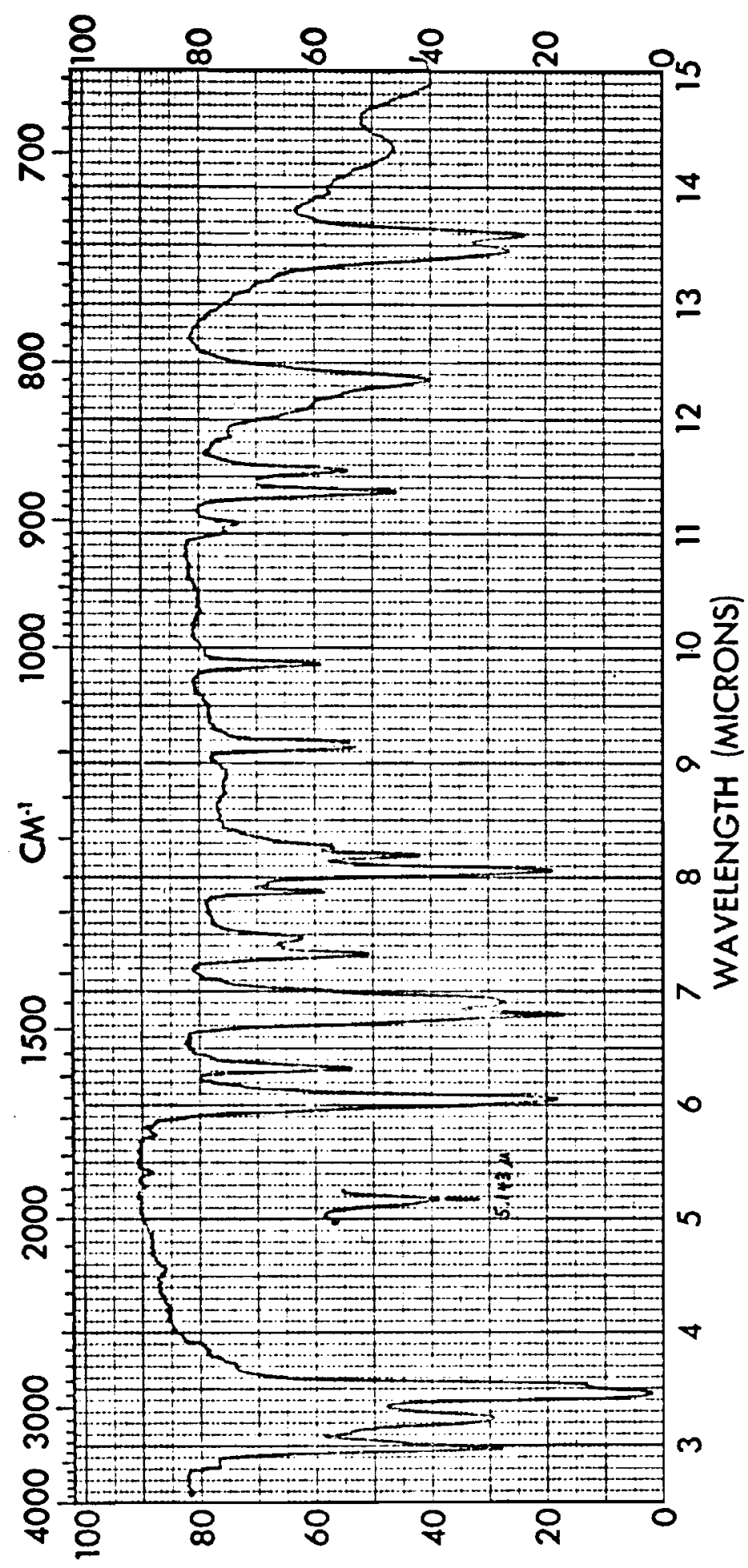

Figure A-2. IR Spectrum of $\left[\left(\mathrm{H}_{2} \mathrm{~N}_{2} \mathrm{C}=\mathrm{NH}_{2}\right]_{2}\left[\mathrm{~S} 1(\mathrm{Cat})_{3}\right] \cdot \mathrm{XH}_{2} \mathrm{O}\right.$ (Nujol Mull). 


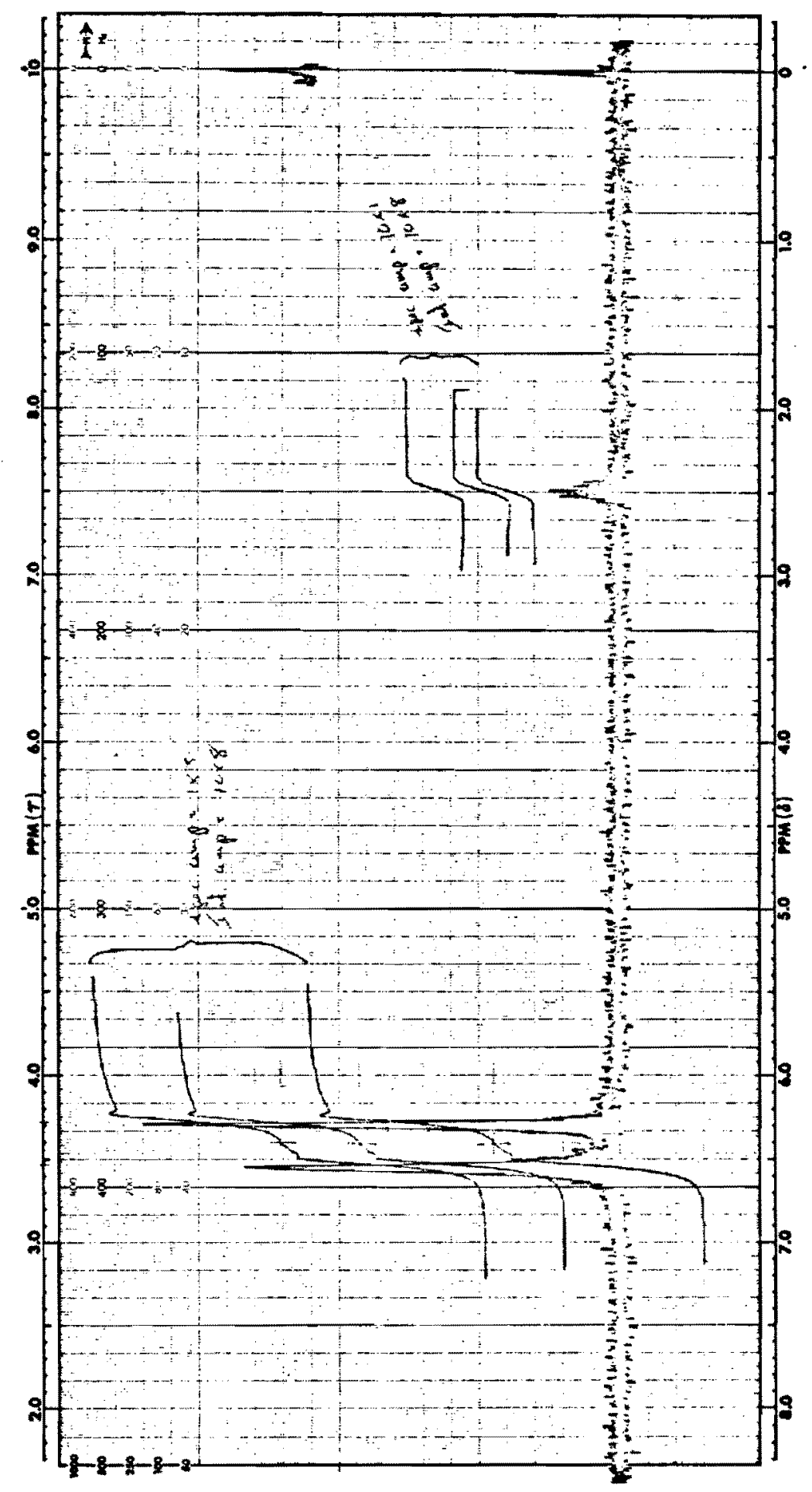

F1gure $\mathrm{A}-3 . \quad$ MRR Spectrum of $\left[\left(\mathrm{H}_{2} \mathrm{~N}\right)_{2} \mathrm{C}=\mathrm{NH}_{2} \mathrm{~b}_{2}[\mathrm{Si} \text { (Cat) })_{3}\right] \cdot \mathrm{XH}_{2} \mathrm{O}$ in Deuterated DMSO (7\% solution). 


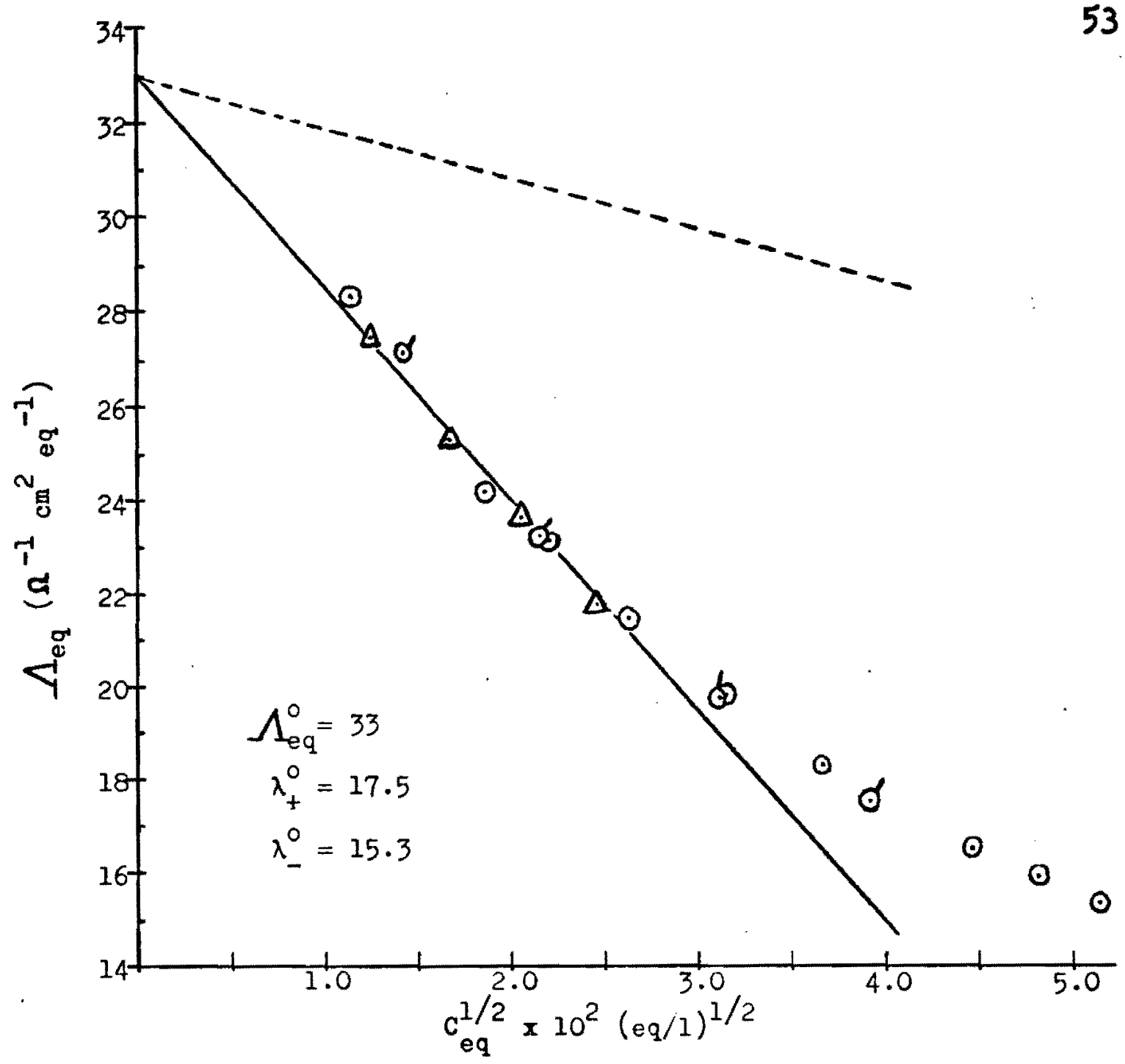

a. Observed limiting slope $(\longrightarrow)=-450$

b. Theoretical limiting slope(----) $=-102$

c. The limiting slope of the plot shown above of $\Lambda_{\mathrm{eq}}^{0}$ vs $\mathrm{c}_{\mathrm{eq}}^{1 / 2}$ for $\left.\left.\mathrm{L}\left(\mathrm{H}_{2} \mathrm{~N}\right)_{2} \mathrm{C}=\mathrm{NH}_{2}\right]_{2} \mathrm{iSi}(\mathrm{Cat})_{3}\right] \cdot \mathrm{XH}_{2} \mathrm{O}$ in DNSO does not approach that predicted by Onsager's theory. It appears that the guanidinium salt forms ion pairs in DMSO.

d. The plot is constructed from data taken from a yet to be published article by Kelley, Barnum, and Eigner titled "Conductivity in Dimethylsulfoxide of Some Electrolytes with Multiply Charged Ions."

Fimare A-4. Equivalent Conductance of Guanidinium Tris(catecholato) siliconate in Disso. 


\section{APPENDIX B \\ X-RAY POWDER DIFFRACTION PATTERNS OF SILICATE MINERALS AND SILICATE IINERAL \\ REACTION RESIDUES}

Powder diffraction patterns were measured with a General Electric XRD-5 $x$-ray spectrometer using a copper target and a nickel filter. $I / I_{O_{0}}=$ relative intensity on a scale running from 0 to $100 ; \mathrm{d} \&=$ distance, in angstrom units, between crystal planes. 
TABLE B-1

X-RAY POWDER DIFFRACTION PATTERNS OF ALBITE

ASTM 9-466

Source: Amelia, Virginia.
Starting Wineral Reaction Residue

Source: Bancroft, Source: Resldue from Ontario, Canada. the reaction of a lbite with catechol@pi 10.

$I / I_{0}:$ Diffractometer $I / I_{0}: D 1 f f r a c t o m e t e r ~ I / I_{0}: V 1$ sual estimate

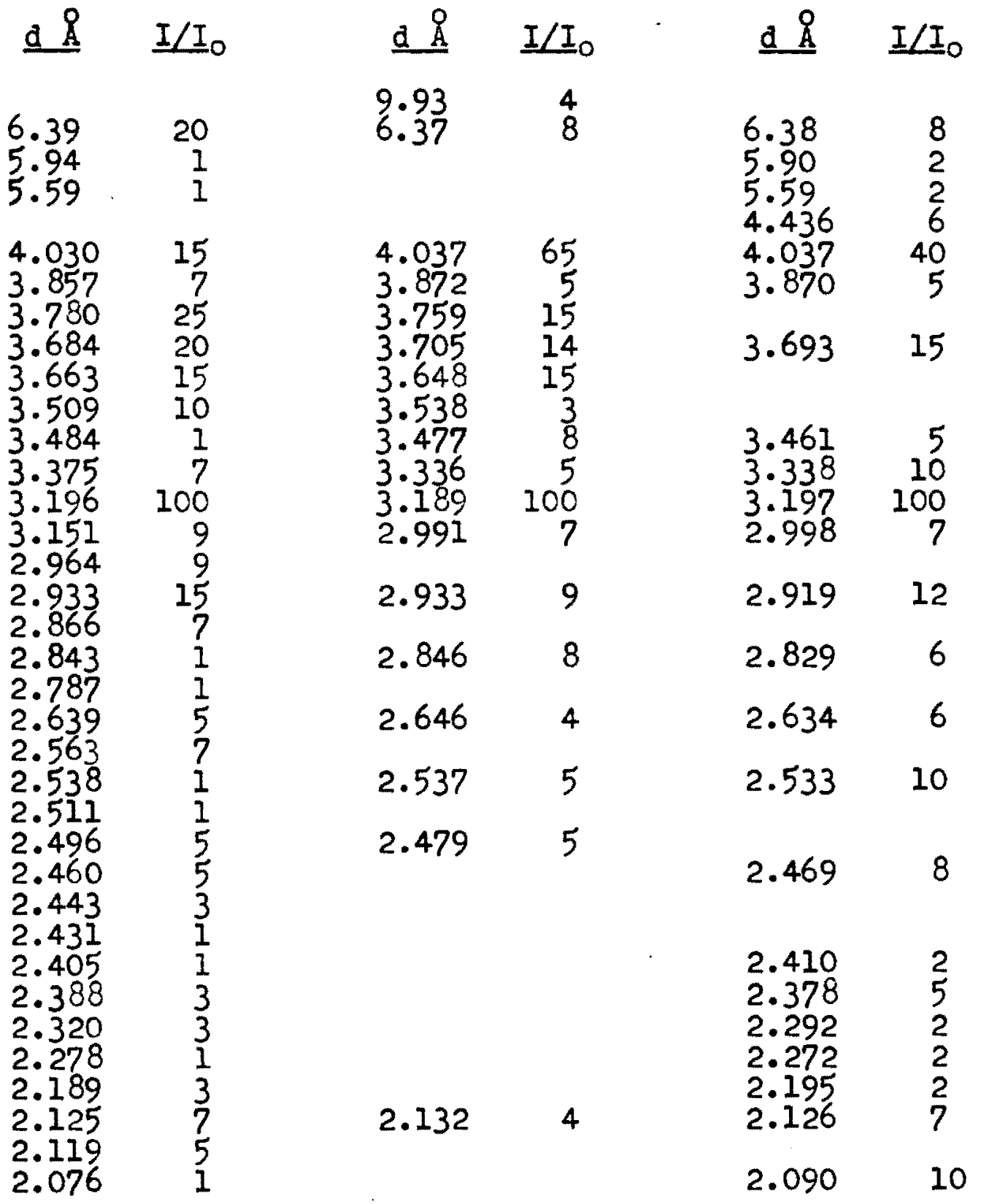


TABLE B-1 (CONT INUED)

\section{ASTM 9-466}

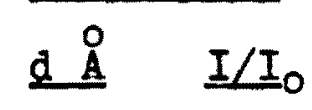

2.035

2.000

1.980

1.927

1.889

1
1
3
1
7
Starting Mineral

$$
\mathrm{d} \AA \quad I / I_{0}
$$

Reaction Residue

d $\AA \quad I / I_{0}$

1.907

7

$1.846 \quad 8$

$1.818 \quad 11$

$1.770 \quad 9$ 
TABLE B-2

Z-RAY POWDER DIFFRACTION PATTERNS OF ANDRADITE

ASTM 10-288

Source: Synthetic.
Starting Hineral Reaction Residue

Source: Eagle Wts., Source: Resldue from Riverside Co., California. the reaction of andradite with catechol@ $\mathrm{pH} 10$.

$I / I_{0}: D$ iffractometer $I / I_{0}: D$ iffractometer $I / I_{0}$ : Visual estimate

\begin{tabular}{|c|c|c|c|c|c|}
\hline $\mathrm{d} \AA$ & $I / I_{0}$ & $\mathrm{~d} \AA$ & $I / I_{0}$ & $\underline{\mathrm{d} \AA}$ & $I / I_{0}$ \\
\hline 4.263 & 13 & 4.25 & 24 & 4.27 & $5-20$ \\
\hline $\begin{array}{l}3.015 \\
2.696 \\
2.571\end{array}$ & $\begin{array}{r}60 \\
100 \\
13\end{array}$ & $\begin{array}{l}3.01 \\
2.69\end{array}$ & $\begin{array}{r}62 \\
100\end{array}$ & $\begin{array}{l}3.000 \\
2.687 \\
2.559\end{array}$ & $\begin{array}{r}80 \\
5\end{array}$ \\
\hline $\begin{array}{l}2.462 \\
2.365 \\
2.202 \\
1.9564 \\
1.9068 \\
1.7406\end{array}$ & $\begin{array}{l}45 \\
17 \\
17 \\
25 \\
11\end{array}$ & $\begin{array}{l}2.45 \\
2.36 \\
2.19 \\
1.95 \\
1.90\end{array}$ & $\begin{array}{l}65 \\
17 \\
17 \\
21 \\
10\end{array}$ & $\begin{array}{l}2.450 \\
2.354 \\
2.189 \\
1.947 \\
1.901 \\
1.734\end{array}$ & $\begin{array}{l}60 \\
10 \\
10 \\
17 \\
13 \\
6\end{array}$ \\
\hline $\begin{array}{r}1.6728 \\
1.6412\end{array}$ & 25 & 1.67 & 25 & 1.665 & 30 \\
\hline $\begin{array}{l}1.6112 \\
1.5073\end{array}$ & $\begin{array}{l}60 \\
13\end{array}$ & $\begin{array}{l}1.61 \\
1.50\end{array}$ & $\begin{array}{l}74 \\
12\end{array}$ & $\begin{array}{l}1.605 \\
1.503\end{array}$ & $\begin{array}{r}100 \\
20\end{array}$ \\
\hline $\begin{array}{l}1.3483 \\
1.3157 \\
1.2856 \\
1.2309\end{array}$ & $\begin{array}{r}13 \\
20 \\
13 \\
3\end{array}$ & $\begin{array}{l}1.35 \\
1.31 \\
1.28\end{array}$ & $\begin{array}{l}11 \\
12 \\
11\end{array}$ & $\begin{array}{l}1.344 \\
1.311 \\
1.282\end{array}$ & 20 \\
\hline $\begin{array}{l}1.1195 \\
1.1008\end{array}$ & $\begin{array}{l}25 \\
15\end{array}$ & $\begin{array}{l}1.12 \\
1.10\end{array}$ & $\begin{array}{l}11 \\
12\end{array}$ & & \\
\hline
\end{tabular}


TABLE B-3

X-RAY POWDER DIFFRACTION PATTERNS OF MUSCOVITE

\section{ASTM 6-0263 Starting Mineral Reaction Resldue}

Source: Not listed. Source: Spruce Pine, Source: Residue from Mitchell Co., North the reaction of Carolina. muscovite with catechol@ $\mathrm{pH} 10$.

$I / I_{0}:$ Geiger counter $I / I_{0}:$ Diffractometer $I / I_{0}:$ Visual estimate d $\AA \quad I / I_{0}$

d $\AA \quad I / I_{0}$

d $\quad I / I_{0}$

$\begin{array}{rr}9.95 & 95 \\ 4.97 & 31 \\ 4.47 & 21 \\ 4.30 & 4 \\ 4.11 & 4 \\ 3.95 & 6 \\ 3.882 & 14 \\ 3.731 & 17 \\ 3.489 & 22 \\ 3.342 & 23 \\ 3.320 & 100 \\ 3.199 & 28 \\ 3.122 & 2 \\ 2.987 & 34\end{array}$

$\begin{array}{rr}11.04 & 4 \\ 10.04 & 100 \\ 5.007 & 38 \\ 4.480 & 4\end{array}$

$\begin{array}{lr}9.99 & 10 \\ 4.968 & 7\end{array}$

$4.453 \quad 70$

4.283

4.103

5

3.889

3.744

3.857

8

3.682

3.723

8

3.490

3.4829

$3.330 \quad 88$

$\begin{array}{ll}3.319 & 15 \\ 3.188 & 10\end{array}$

3.092

6
7
7

$2.859 \quad 24$

2.986

$2.980 \quad 10$

2.789

2.952

$2.857 \quad 8$

$2.790 \quad 6$

2.781

6

2.596

2.565

$2.579 \quad 100$

2.505

16

54

$2.491 \quad 14$

2.465

2.493

5

2.450

2.398

8

2. 384

7

2.396

2.453

9

2.254

2.236

27

2

2.378 15

2.208

2.189

9

2.149

2.132

2.070

2.053

4
7
4
15
21
4
6

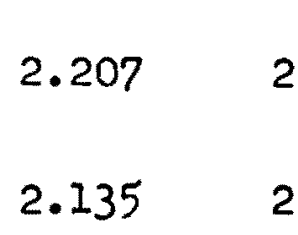

2.241

2.202

2.175

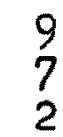

$2.128 \quad 14$

$2.054 \quad 5$ 
TABLE B-3 (CONTINUED)

ASTH 6-0263

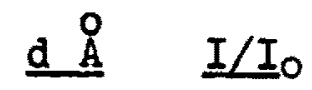

1.993

1.951

1.941

1.894

1.871

1.822

1.746

1.731

1.710

1.704

1.699

1.662

1.646

1.631

1.620

1.603

1.573

1.559

1.541

1.524

1.504

1.453

1.424

1.414

1.388

1.375

1.352

1.335

1.321

1.299

1.292

1.274

1.267

1.253

1.246

11

23

6

6

3

13

30

4

1

1

1

2

11

9

3

6

5

4

5
Starting Mineral

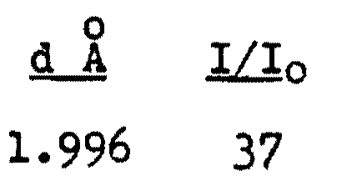

1.731

1.658
1.645

2
4

2

1.721

$\begin{array}{ll}1.696 & 5 \\ 1.656 & 5\end{array}$

Reaction Residue

$\begin{array}{cc}\mathrm{d} \AA & \mathrm{I} / \mathrm{I}_{\mathrm{O}} \\ 1.984 & 10 \\ 1.960 & 3 \\ 1.940 & 2\end{array}$

$1.638 \quad 10$

$\begin{array}{ll}1.595 & 5 \\ 1.575 & 5\end{array}$

1.515
1.495 $\quad 60$

1.351

5

$1 \cdot 347$
$1 \cdot 334$

5
2

$\begin{array}{lr}1.294 & 15 \\ 1.270 & 5\end{array}$

1.2453 
TABLE B-4

X-RAY POWDER DIFFRACTION PATTERNS OF PYROPHYLLITE

ASTM 2-0613

Source: Tres

Cerritos, liariposa

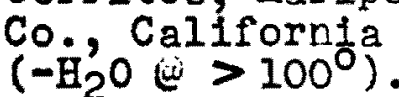

Starting Lineral

Source: Tres

Cerritos, Mariposa

Co., California.

\section{Reaction Residue}

Source: Residue from the reaction of pyrophyllite with catechol@ pH 10.

$I / I_{0}: V 1$ sual estimate $I / I_{0}:$ Diffractometer $I / I_{0}: V 1$ sual estimate

\begin{tabular}{|c|c|c|c|c|c|}
\hline d 8 & $I / I_{0}$ & $\underline{\mathrm{d}} \AA$ & $I / I_{0}$ & $\mathrm{~d} \AA$ & $I / I_{0}$ \\
\hline 9.14 & 40 & $\begin{array}{c}20.04 \\
9.11\end{array}$ & $\begin{array}{r}4 \\
100\end{array}$ & 9.32 & 10 \\
\hline 4.57 & 50 & 4.583 & 50 & 4.590 & 5 \\
\hline & & $4.237^{*}$ & 6 & $4.259 *$ & 25 \\
\hline $\begin{array}{l}4.15^{*} \\
3.87\end{array}$ & $\begin{array}{r}20 \\
5\end{array}$ & & & & \\
\hline & & $\begin{array}{l}3.697 \\
3.379\end{array}$ & $\begin{array}{l}2 \\
4\end{array}$ & 3.717 & 7 \\
\hline $\begin{array}{l}3.34 * \\
3.04\end{array}$ & $\begin{array}{c}20-40 \\
100\end{array}$ & $\begin{array}{l}3.336 * \\
3.074\end{array}$ & $\begin{array}{l}42 \\
88\end{array}$ & $\begin{array}{l}3.338 * \\
3.072 \\
2.562\end{array}$ & $\begin{array}{r}100 \\
15 \\
15\end{array}$ \\
\hline 2.52 & 20 & $2.453 *$ & 12 & 2.533 & 15 \\
\hline $\begin{array}{l}2.40 \\
2.20^{*}\end{array}$ & $\begin{array}{l}40 \\
20\end{array}$ & $\begin{array}{l}2.453^{*} \\
2.409 \\
2.203^{*}\end{array}$ & $\begin{array}{r}13 \\
2 \\
5\end{array}$ & $\begin{array}{l}2.412 \\
2.280^{*} \\
2.235^{*} \\
2.150\end{array}$ & $\begin{array}{r}13 \\
30 \\
15 \\
10 \\
5\end{array}$ \\
\hline $\begin{array}{l}2.14 * \\
2.07 \\
2.04 \\
1.88\end{array}$ & $\begin{array}{c}10-20 \\
10 \\
10 \\
5\end{array}$ & & & $\begin{array}{l}2.128^{*} \\
2.083 \\
2.054 \\
1.938^{*}\end{array}$ & $\begin{array}{r}10 \\
5 \\
5 \\
10\end{array}$ \\
\hline $1.83^{*}$ & 40 & $\begin{array}{l}1.836^{*} \\
1.812^{*} \\
1.668^{*}\end{array}$ & $\begin{array}{r}10 \\
3 \\
2\end{array}$ & $\begin{array}{l}1.813^{*} \\
1.669^{*}\end{array}$ & $\begin{array}{l}30 \\
10\end{array}$ \\
\hline $\begin{array}{l}1.64 \\
1.62 \\
1.57\end{array}$ & $\begin{array}{c}20-40 \\
10-20 \\
3\end{array}$ & & & & \\
\hline $\begin{array}{l}1.52 \\
1.49\end{array}$ & $\begin{array}{c}10 \\
20-40\end{array}$ & $\begin{array}{l}1.538 * \\
1.529\end{array}$ & $\begin{array}{l}3 \\
2\end{array}$ & $\begin{array}{l}1.540 * \\
1.489\end{array}$ & 30 \\
\hline
\end{tabular}

* These lines indicate the presence of $\alpha$-quartz. 
TABLE B-4 (CONTINOED)

ASTM 2-0613

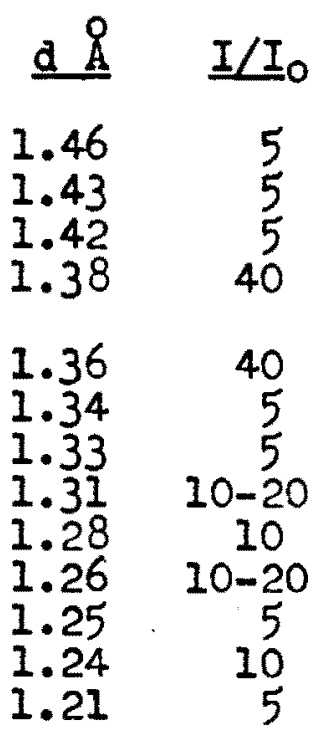

Starting Mineral Reaction Residue

$$
\begin{array}{cccc}
\mathrm{d} \AA & \mathrm{I} / \mathrm{I}_{0} & \underline{\mathrm{d} \AA} & \mathrm{I} / I_{0} \\
& & 1.468 & 5 \\
& & 1.453 & 5 \\
1.381 & 3 & 1.382 & 20 \\
1.370 & 3 & 1.372 & 30 \\
& & & \\
& & & \\
& & & \\
& & 1.285 & 10 \\
& & 1.265 & 5 \\
& & &
\end{array}
$$


TABLE B-5

X-RAY POWDER DIFFRACTION PATTERNS OF TALC

\section{ASTM 13-558}

Source: manchuria.

\section{Starting lineral}

Source: Unknown.

\section{Reaction Residue}

Source: Resldue from the reaction of talc with catechol@pH 10.

$I / I_{0}:$ Diffractometer $I / I_{0}:$ Diffractometer $I / I_{0}:$ Visual estimate

$\underline{\mathrm{d}} \quad \mathrm{I} / \mathrm{I}_{\mathrm{O}}$

$9.34 \quad 100$

4.66 .90

$4.55 \quad 30$

$3.51 \quad 4$

$3.43 \quad 1$

3.116100

2.892

2.629

2.595

2.476

2.335

2.212

2.196

2.122

2.103

1.930

1.870

1.725

1.682

1.557

1.527

1.509

1.460

1.406

1.394

1.336

1.318

1.297

1.269

1.169

$\frac{1}{12}$

30

65

16

20

10

20

40

$--$

20

20

40

10

8

16

20

16

10

10

10
6 d $I / I_{0}$ $10.37 \quad 6$

9.39100

5.20
4.68

2.477

3.453
3.118

6

$1.871 \quad 11$

1.5596

$\begin{array}{ll}1.396 & 1 \\ 1.336 & 5\end{array}$ $\mathrm{d} \AA \quad I / I_{0}$

$15.44 \quad 50$

9.4490

$4.571 \quad 80$

$4.187 \quad 10$

$3.093 \quad 70$

$2.614 \quad 15$

$2.582 \quad 30$

2.461100

2.19920

$2.092 \quad 10$

$\begin{array}{rr}1.863 & 5 \\ 1.719 & 10 \\ 1.701 & 8\end{array}$

$\begin{array}{rr}1.518 & 80 \\ 1.501 & 8\end{array}$

$1.169 \quad 1$ $\begin{array}{rr}1.313 & 15 \\ 1.291 & 10 \\ 1.264 & 8\end{array}$ 
TABLE B-6

X-RAY POWDER DIFFRACTION PATTERN OF WOLLASTONITE

\section{ASTM 10-487}

Source: Chiapas, Mexico.

$I / I_{0}:$ V1sual estimate

d $\quad I / I_{0}$

$7.7 \quad 40$

$4.05 \quad 10$

$3.83 \quad 80$

$3.52 \quad 80$

$3.40 \quad 5$

$3.31 * \quad 80$

$3.16 \quad 5$

3.0930

$2.97 * * 100$

$2.80 \quad 10$

$2.72 \quad 10$

$2.55 * * 30$

$2.47 \quad 60$

2.3340

$2.29 \quad 40$

2.1860

2.08** 5

2.0120

$1.98 \quad 20$

$1.91 \quad 20$

1.8820

$1.86 \quad 10$

$1.83 \quad 60$

$\begin{array}{rr}1.80 & 5 \\ 1.75 & 40\end{array}$

$1.72 * * 60$

$1.602 * 40$

$1.531 * 10$

$\begin{array}{ll}1.515 & 5 \\ 1.478 * & 50\end{array}$
Starting Mineral

Source: Calico, San

Bernadino Co., California.

$I / I_{0}:$ Diffractometer

$\underline{\mathrm{d} \AA} \quad \underline{\mathrm{O}} / \mathrm{I}_{\mathrm{O}}$

$7.65 \quad 32$

$5.43 \quad 4$

4.247* 9

3.83899

$3.517 \quad 57$

$3.320 * 100$

$3.241 \quad 6$

$3.087 \quad 19$

$2.976 \quad 10$

$2.720 \quad 10$

$2.558 \quad 21$

$2.339 \quad 9$

2.30221

$\begin{array}{ll}2.182 & 4 \\ 2.167 & 5\end{array}$

$\begin{array}{ll}1.982 & 3 \\ 1.918 & 10\end{array}$

$1.811 * 6$

$1.757 \quad 14$

$1.537 * 19$

* These Ines indicate the presence of $\propto$-quartz.

** These lines indicate that the ASTM sample contained magnetite. 
TABLE B-7

X-RAY POWDER DIFFRACTION PATTERN OF THE

CALCITE RESIDUE RECOVERED AFTER

THE REACTION OF WOLLASTONITE

WITH CATECHOL AT pH 10.0

ASTM 5-0586 (Calcite)

$I / I_{0}:$ Diffractometer

d $I / I_{0}$

$3.86 \quad 12$

3.035100

$2.845 \quad 3$

$2.495 \quad 14$

$2.285 \quad 18$

$2.095 \quad 18$

$1.927 \quad 5$

$1.913 \quad 17$

$1.875 \quad 17$

$1.626 \quad 4$

$1.604 \quad 8$

1.587

$1.525 \quad 5$

1.5184

1.510

1.473

1.440

1.422

1.356

1
Reaction Resldue

$I / I_{0}:$ Visual estimate

$\underline{\AA} I / I_{0}$

4.259* 15

$3.333 * \quad 90$

$3.027 \quad 100$

2.48520

2.443* 7

2. $272^{*} \quad 30$

2.224* 3

2.113* ?

$2.081 \quad 25$

1.965

1.904

$1.863-25$

$1.806 * 17$

$1.659 * 5$

1.61610

1.594* 20

$1.534 * 10$

1.5188

1.471

$1.433 \quad 17$

$1.415 \quad 10$

1.375* 8

$1.368 \quad 15$

* These Innes indicate that $\propto$-quartz is also present. 
TABLE B-8

X-RAY POFDER DIFFRACTION PATTERN OF THE QOARTZ RESIDUE RECOVERED AFTER THE REACTION OF WOLLASTONITE WITH CATECHOL AT $\mathrm{pH} 4.0$

ASTM 5-0490 ( $\alpha-$ Quartz)

$I / I_{0}:$ Diffractometer

d $\quad I / I_{0}$

$4.26 \quad 35$

3.343100
Reaction Residue

$I / I_{0}:$ Visual estimate

d $8 I / I_{0}$

$\begin{array}{rr}5.310 & 2 \\ 4.300 \quad 60\end{array}$

$3.705^{*} 5$

$3.328 \quad 100$

$3.000 * 7$

2.801* 2

2.728* 2

$2.536 * 9$

$2.456 \quad 15$

$2.285 \quad 15$

2.23910

$2.126 * 14$

$2.014 \quad 5$

$1.981 \quad 10$

1.81760

$1.673 \quad 15$

1.657

1.627

1.542

$1.453 \quad 10$

$1.382 \quad 20$

1.37250

$1.287 \quad 10$

$1.256 \quad 10$

$1.228 ?$

* These IInes Indicate that a trace of wollastonite is still present. 


\section{APPENDIX C}

\section{X-RAY POWDER DIFFRACTION PATTERN AND INFRARED AND NMR SPECTRA OF AN UNIDENTIFIED \\ CALCIULI SALT, CORPOUND A}

A Perkin-Elmer 137 B INERACORD spectrophotometer was used to obtain infrared spectra. The nor spectrum was obtained by using a Varian A-60 nmr spectrometer.

The powder diffraction pattern was measured with a General Electric XRD-5 $x$-ray spectrometer using a copper target and a nickel filter. $I / I_{0}=$ relative intensity on a scale running from 0 to $100 ; d \AA=$ distance, in angstrom units, between crystal planes. 
TABLE C-1

X-RAY POWDER DIFFRACTION PATTERN OF COMPOUKD A

$\begin{array}{cc}\text { Radiation: CuK } \propto & I / I_{0}: \text { Diffractometer } \\ \text { a } \AA & I / I_{0} \\ 11.70 & 8 \\ 10.64 & 100 \\ 9.55 & 25 \\ 8.83 & 13 \\ 8.58 & 7 \\ 8.07 & 12 \\ 6.39 & 4 \\ 6.21 & 6 \\ 5.71 & 2 \\ 4.99 & 6 \\ 4.831 & 16 \\ 4.350 & 10 \\ 4.149 & 6 \\ 4.037^{*} & 3 \\ 3.847^{*} & 8 \\ 3.782^{*} & 9 \\ 3.517^{*} & 5 \\ 3.324^{*} & 8 \\ 3.092^{*} & 4 \\ 2.991^{*} & 5 \\ 2.732^{*} & 3 \\ 2.558 * & 2 \\ 2.486^{*} & 5 \\ 2.308^{*} & 2 \\ 1.760^{*} & 1\end{array}$

* These lines indicate the presence of wollastonite. 


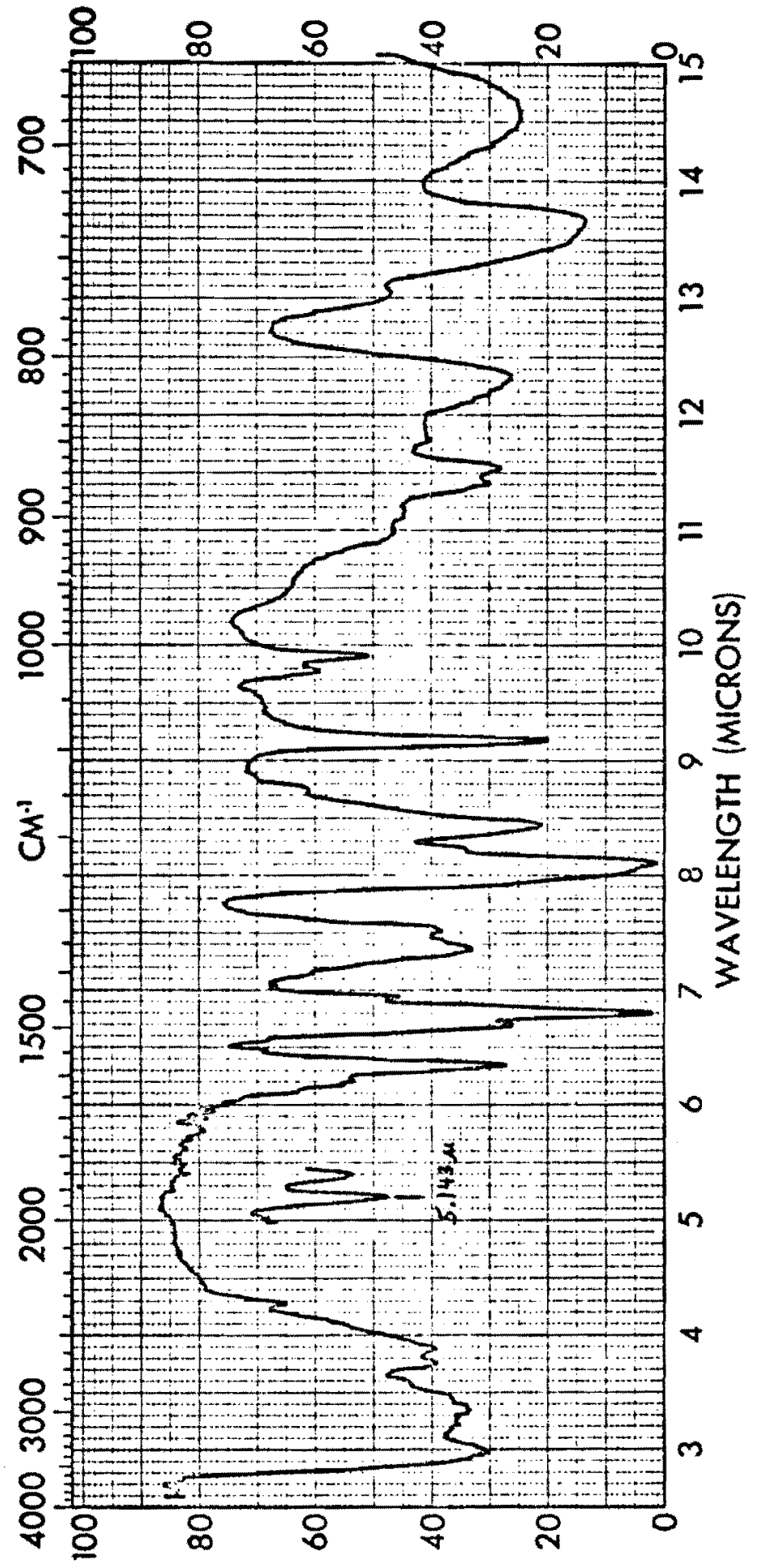

Figure C-1. IR Spectrum of Compound A. 

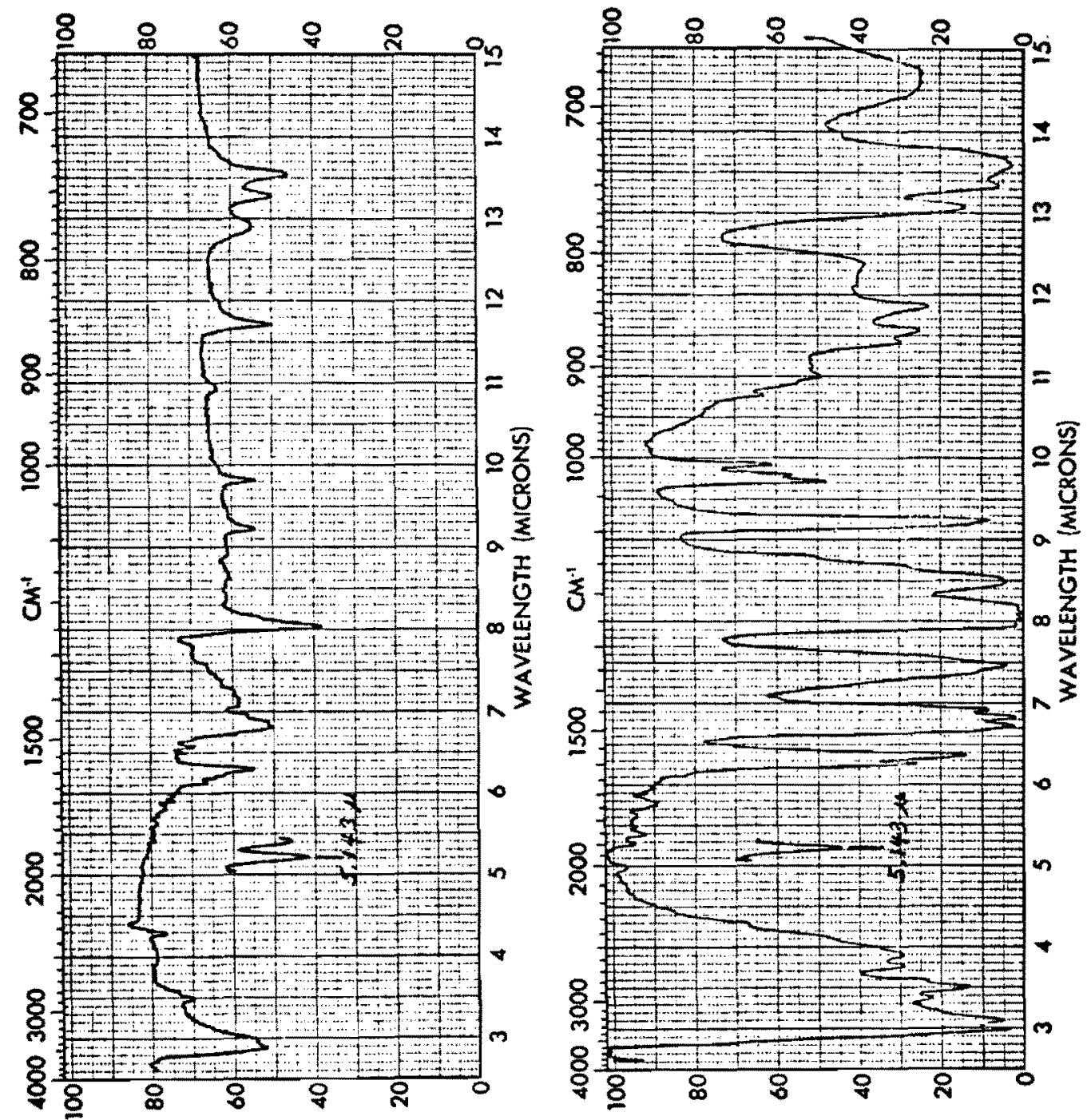

F1gure C-2. IR Spectra of:

Top - $\mathrm{Ca}$ (HCat) $2 \cdot \mathrm{XH}_{2} \mathrm{O}$

Bottom - Compound A Contaminated with Catechol 


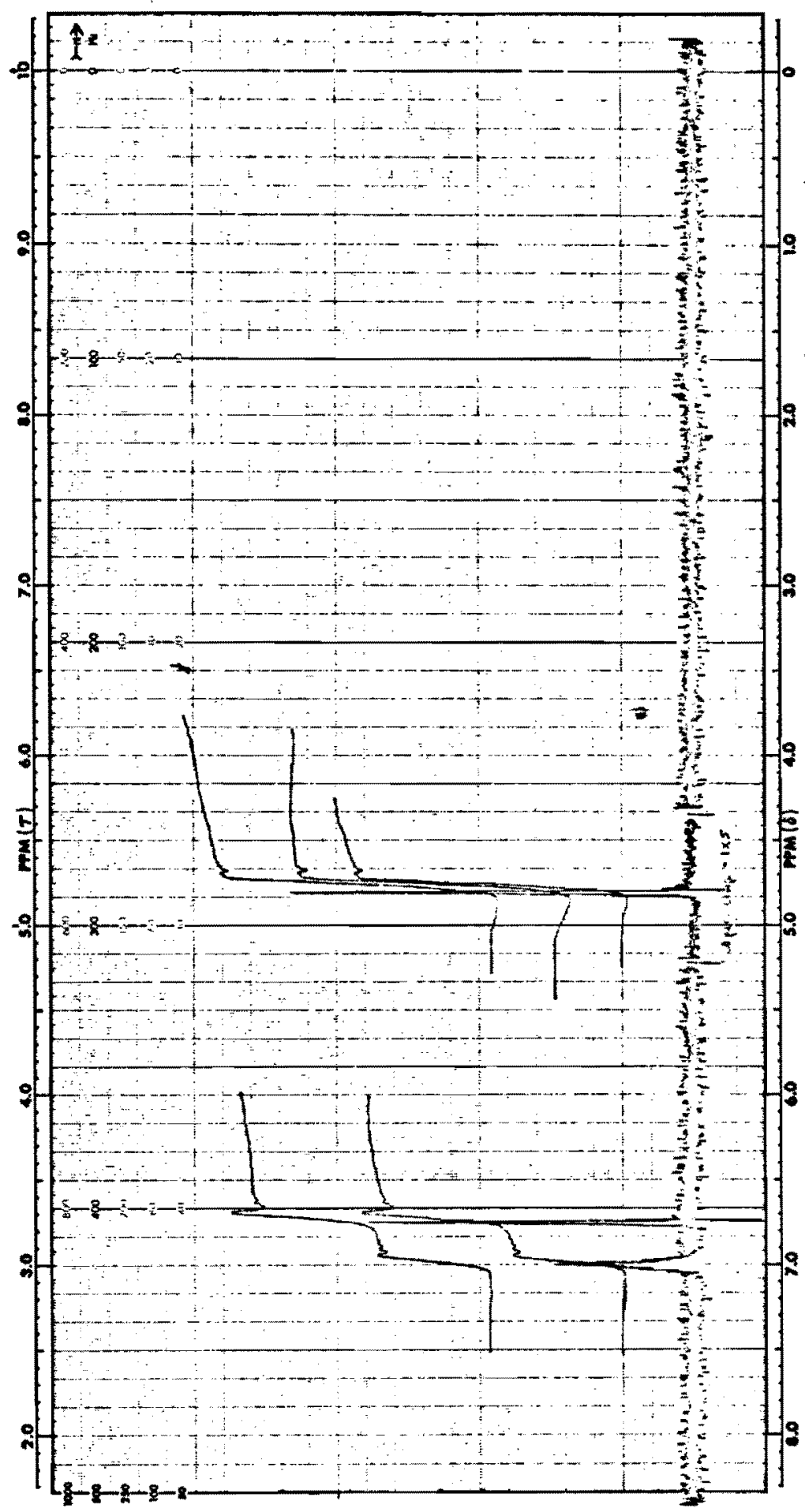

Flgure C-3. NMR Spectrum of Compound $A$ in $\mathrm{D}_{2} \mathrm{O}$ (Saturated solution). 